Egyptian Journal of Aquatic Biology \& Fisheries

Zoology Department, Faculty of Science,

Ain Shams University, Cairo, Egypt.

ISSN $1110-6131$

Vol. 24(2): 555 - 590 (2020)

www.ejabf.journals.ekb.eg

\title{
Monograph of the Egyptian Cuttlefishes \\ Order: Sepioidea; Cephalopoda: Mollusca (Part I)
}

Rafik Riad

National institute of Oceanography and Fisheries, Alexandria

Corresponding author: Rafik_riad@yahoo.com

\section{ARTICLE INFO}

Article History:

Received: March 5, 2020

Accepted: April 28, 2020

Online: April 30, 2020

Keywords:

Monograph,

Egyptian,

Red Sea,

Mediterranean,

cuttlefishes,

Sepioidea,

Mollusca.

\begin{abstract}
Class Cephalopoda includes cuttlefishes, squids, octopuses and nautili, which are very important ecologically and commercially. Species of the first three groups are present in the Egyptian Mediterranean and Red Seas. They constitute a main component in the fisheries industry. In order to understand the biology and ecology of different species, their identification should be conducted properly to maximize the accuracy of any study. The present monograph is the first-in-kind for this group and has been prepared to demonstrate an identification key for the cuttlefish species in the Egyptian waters. Second and third monographs that cover squids and octopuses will be published in the near future. Eight cuttlefish species were recorded in the Egyptian waters. These are Sepia officinalis, S. elegans, S. dollfusi, S. pharaonis, S. elongate, S. parashadi, S. savignyi and Rossia macrosoma. The identification was done using morphometric characteristics, which were dissected, photographed and drawn.
\end{abstract}

\section{INTRODUCTION}

Cuttlefishes, squids, octopuses and nautili are the most important representatives of class Cephalopoda. The class includes about 1000 known species, which represent about 2.07\% of phylum Mollusca (Hassan, 1974). As a group they includes the largest species of both modern and fossil invertebrates in both the coastal and the oceanic waters, inhabiting different kinds of grounds. Commercially, they represent a remarkable and significant fishery in many areas of the world. From the total catch of world cephalopod fishery, about $71.8 \%$ were squids, $13.6 \%$ cuttlefishes and $14.6 \%$ octopuses (Jereb \& Roper 2005).

Many studies at the beginning of the 19th century concentrated on the northern part of Gulf of Suez fauna. Savigny (1817) was the first who mentioned cephalopoda in Red Sea; he also identified 70 species that were not reconfirmed before in the Red Sea waters 
(Edwards and Head, 1987). In the 20th century the Red Sea became an exciting direction to many expeditions. Although most of these expeditions aim was oceanographic explorations, they also brought a zoogeograhical studies with regional details (Edwards and Head, 1987). Robson (1926) recorded 3 cephalopods species from the Cambridge Expedition to the Suez Canal. They were Ascarosepion singhalensis (Goodrich), which is synonymous to Sepia pharaonis Ehrenberg, 1831, Lophosepion lefebrei d'Orbigny Synonymous to Sepia gibba Ehrenberg, 1831, and Octopus horridus d'Orbigny (zebra octopus). Robson (1926) recorded six cephalopod species from the Suez Canal. Adam (1959) described 10 , 3 cephalopods of Gulf of Suez and Gulf of Aqaba, respectively. Adam (1960) recorded 7 cephalopod species from Aqaba Gulf. Emam (1983) recorded 8 cephalopods from Gulf of Suez. and Aqaba. About 10 Sepioidea species were recorded in the Egyptian waters ( Steuer, 1939; Emam,1983; Riad, 1993; Riad, 2000a\& b; Riad, 2008a \&b; Riad, 2015.). Steuer (1939) recorded Sepia officinalis from Abu Qir Bay. The morphometry of three species Sepia officinalis from the Mediterranean sea, Sepia prashadi and Sepia savignyi from the Red sea were studied by Emam (1983). Riad (1993) recorded 9 cephalopoda species from the Egyptian Mediterranean waters; two of them were sepioidea, Sepia officinalis and Sepia elegans. Emam et al (2000) studied the male reproductive system of the Seoioteuthis lessoneana from Suez Gulf. Emam et al (1998) studied the morphometric and population dynamics of Sepia dollfusi from the north region of the Red sea. Riad (2008a) recorded 10 cephalopod species from Suez Gulf and Red Sea; 3 of them were sepioidea Sepia dollfusi, Sepia pharaonis and Sepia elongate Riad (2008b) recorded one new recorded cephalopoda species Sepioteuthis lisoniana from the Egyptian Mediterranean waters migrated from the Red sea. Emam and Gareb (2010) studied morphology, digestiyle and reproductive system of male Sepioteuthis lessoniana from Abo Qir Bay, Mediterranean waters. Riad (2000b) recorded one new record Mediterranean Sepioidea species Rossia macrosoma .. Riad (2015) recorded one new record Sepioidea species Sepia dollfusi from the Egyptian Mediterranean waters migrated from the Red sea through Suez Canal.

The present monograph demonstrates an identification key of cuttlefish in the Egyptian waters, using morphometric features. To enhance the use of the identification key, images and drawings were added to the monograph. The aim of the present work is to collect and obtain more information about the poorly taxonomical studies on Sepioidea species of the Egyptian Red Sea and Mediterranean waters.

\section{MATERIALS AND METHODS}

According to Jereb \& Roper (2005), the following characters were carefully examined for the identification of the species: External morphology, tentacular club, hectocotylized arm, tentacular club sucker, tentacular club sucker ring, arm sucker, arm sucker ring, radula, gill, shell and funnel (siphon). Specimen parts were drawn by means of a zoom 
stereoscopic microscope provided with a camera lucida drawing tube. The specimen parts were also photographed by Canon digital Camera.

\section{RESULTS AND DISCUSSION}

The present monograph demonstrated the identification key of the eight Egyptian cuttlefish species that were recorded in the Egyptian waters. The species are as follows:

\section{Phylum: Mollusca}

Class: Cephalopoda Cuvier, 1798.

Subclass : Coleoidea Bather, 1888.

Order: Sepioidea Naef, 1916.

Family(a): Sepiidae Keferstein, 1866.

Genus Sepia Linnaeus, 1758

1-Sepia officinalis Linnaeus, $1758 . \quad$ Alexandria, Mediterranean waters.

2-Sepia elegans Blainville, $1827 . \quad$ Alexandria, Mediterranean waters.

3-Sepia dollfusi Adam, 1941b. Suez Gulf, Red Sea \& Alexandria, Mediterranean waters.

4-Sepia pharaonis Ehrenberg, 1831. Suez Gulf, Red Sea.

5-Sepia elongata d' Orbigny, 1839 - 1842. Suez Gulf, Red Sea

6-Sepia prashadiWinckworth, 1936

Suez Gulf, Red Sea.

7-Sepia savignyi Blainville, 1827.

Suez Gulf, Red Sea.

Family (b):Sepiolidae Leach, 1817.

SubfamilyRossiinae Appellof, 1898.

Genus:Rossia. Owen, 1834.

Rossia macrosoma (Delle Chiaja, 1829) Alexandria, Mediterranean waters.

\section{Sepioidea general structure}

This description was summarized from Hickman (1973), Juanico (1983) and Jereb \&Roper (2005). Generally the body in the cephalopoda is bilaterally symmetrical. The anterior part of the foot is fused with the head (hence their name), and the posterior part forms an exit funnel from the mantle cavity. The mantle is highly muscular and is posterior of the mouth, the appendages and the eyes. It bears two large eyes, sometimes covered with membrane. In cuttlefishes and squids the mobile appendages surrounding the mouth, consist of eight arms with two rows of suckers in squids and more than two in cuttlefishes. All suckers bear chitinous rings. In addition to the arms there are two longer tentacles (plate1). The mouth has a chitinous beak and a chitinous tongue like radula, a 
band of teeth. The shell is internal except in Nautilus. The body of the cephalopoda is soft. Cuttlefishes are characterized by lateral fins extending along the mantle (Plate 1).

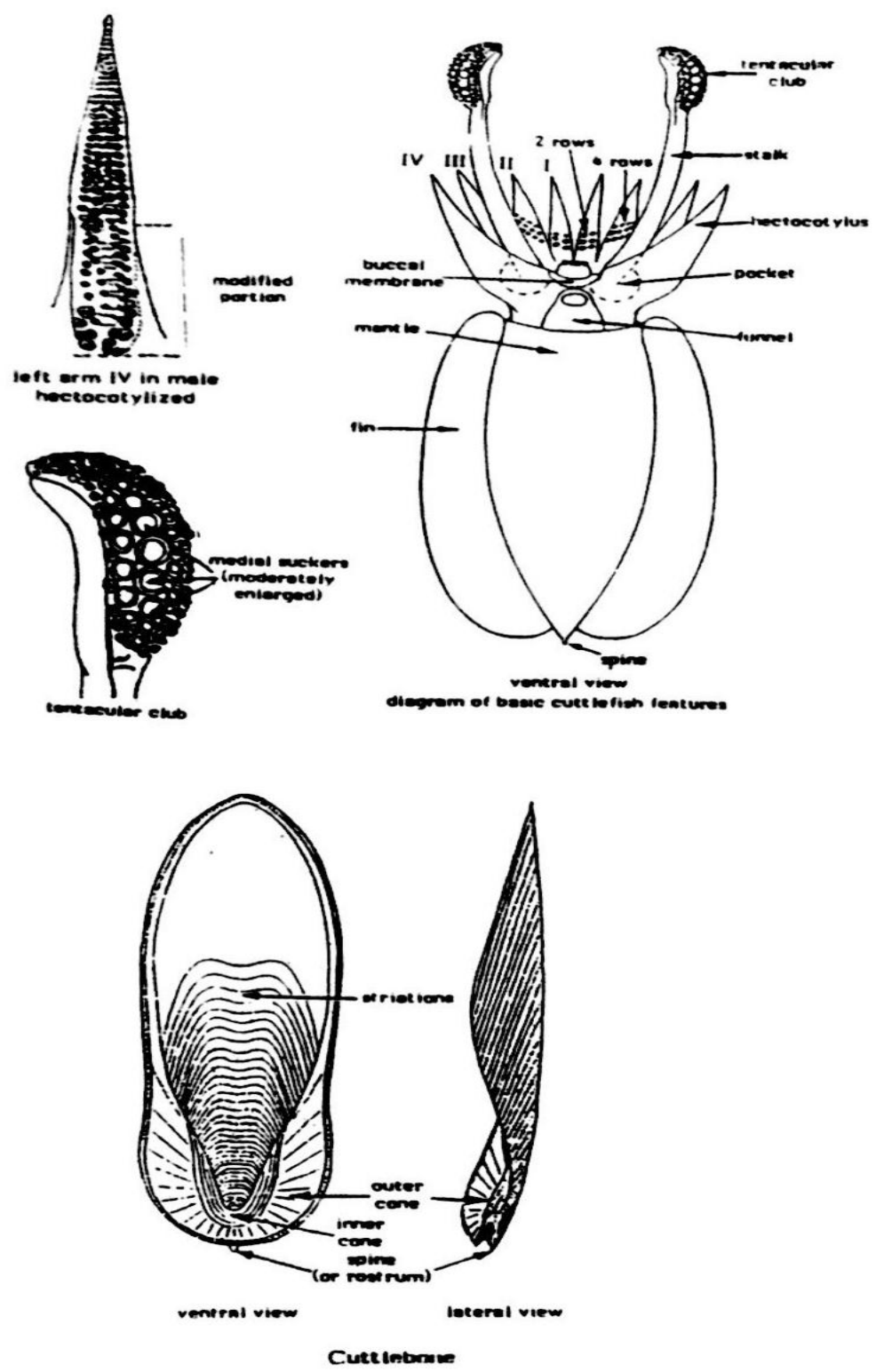

PLATE 1: External structure of cuttlefishes

(Redrawn from Jereb \& Roper, 2005) 


\section{Phylum: Mollusca}

Class: Cephalopoda Cuvier, 1798

Subclass: Coleoid Bather, 1888

The Subclass Coleoidea embraces four orders; Sepioidea Naef, 1916; Tauthoidea Naef, 1916; octopoda Leach, 1818 and Vampyromorpha Pickford, 1939

\section{Order :Sepioidea Naef,1916}

This order is characterized by the following features: shell calcareous or chitinous; 10 circumoral appendages; tentacles retractile into pockets; suckers with chitinous rings; posterior fin lobes free, not connected at midline; eyes covered with a transparent membrane, false eyelids present; one pair of gills, without branchial canal between afferent and efferent branchial blood vessels; liver divided or bilobed, each tooth of radula with a single projection; buccal membrane present; olfactory organ a ciliated pit. This order comprises five families: Spirulidae Owen, 1836, Sepüdae Keferstein,1866 Sepiadariidae Naef, 1912), SepiolidaeLeach,1817 and Sepiadariidae Owen,1836, Sepiidae Keferstein 1866 , Appellf, 1898. In Egyptian Mediterranean and Red Sea waters this order is represented by only one family: Sepiidae, which have significant commercial value.

1.3 Sepioidea species of the East Mediterranean waters (Jereb \& Roper, 2005;

Katagan \& Kocatas, 1990).

Seven Sepioidea species are known to occur in the Mediterranean waters: Sepia elegans BlainVille, 1827; Sepia officinalis Linnaeus, 1758; Sepia orbignyana Ferussac. 1826; Sepiola rondeleti Leach, 1817; Sepietta oweniana d'Orbigny, 1840; Rondeletiola minor Naef, 1912 and Rossia macrosoma Delle chiaje, 1829.

\section{Sepioidea of the Egyptian waters (Mediterranean and Red sea).}

The following species were recorded as follows:

Class : Cephalopoda Cuvier, 1798.

Subclass : Coleoidea Bather, 1888.

Order: Sepioidea Naef, 1916.

Family(a): Sepiidae Keferstein, 1866.

Genus Sepia Linnaeus, 1758 1-

1-Sepia officinalis Linnaeus, 1758.

2-Sepia elegans Blainville, 1827.

3-Sepia dollfusi Adam, 1941b.

4-Sepia pharaonis Ehrenberg, 1831.

5-Sepia elongata d' Orbigny, 1839 - 1842. 
6-Sepia prashadiWinckworth, 1936.

7-Sepia savignyi Blainville, 1827.

Family(b):Sepiolidae Leach, 1817.

subfamilyRossiinae Appellof, 1898.

Genus:Rossia. Owen, 1834.

Rossia macrosoma (Delle Chiaja, 1829)

\section{Morphology and occurrence of the Sepioidea species of Egyptian waters.}

Family(a):Sepiidae Keferstein, 1866.

Inner shell (cuttlebone) is an oval calcified body lighter than water, porous, finely laminate, Mantle broad, robust, sac- like, slightly flattened dorso ventrally; surrounded by a pair of narrow fins of nearly equal to mantle length; fins never join posteriorly, not connected at midline; ten circumoral appendages two of which are longer than the others and are modified for capture of prey; arms with two to four, and tentacles with four to eight more longitudinal rows of suckers; tentacles retractile into pockets on ventro lateral sides of head. Eyes covered with a corneal membrane. Colour, variable due to the great complex of chromatophores (pigment cells); browns, blacks, yellows, and reds are the dominating colours. Left ventral arm IV of the male hectocotylized. This family embraces two genera: Sepia Linnaeus 1758 and Sepiella Gray, 1849. (Jereb \& Roper, 2005)

In the present work Genus Sepia is only represented.

Genus: Sepia Linnaeus, 1758

Cuttlebone with spine (rostrum) presents on posterior end (occasionally damaged or absent); as long as the body; bordered by a horny margin. No glandular pore on ventral surface at posterior end of mantle. This genus is represented by seven species, Sepia officinalis Linnaeus, 1758 ; Sepia elegans Blainville, 1827; Sepia dollfusi; Sepia pharaoni;Sepia elongate; Sepia prashadi and Sepia savignyi.

\section{Key to the recorded species of genus Sepia in the present monograph}

*The tentacular club is provided with transverse rows of suckers, 5 or 6 in each, the median longitudinal row remarkably enlarged, Left arm IV hectocotylized is reduced in size, with 5-8 horizontal rows of reduced suckers Sepia officinalis.

* The tentacular club is short with 6 to 8 suckers on each transverse row; few of the suckers are enlarged while 3 are greatly developed in the center. 
Two thirds of the left arm IV hectocotilized possess about 9-11 zigzag rows of minute suckers ..Sepia elegans.

* Tentacular club has 5-7 suckers in middle row larger than others.

Left arm IV hectocotylized modified in the about half terminal part forward by 12 transversal rows of 4 minute suckers Sepia dollfusi.

*The middle part of the tentacular club bearing 8 transverse rows of suckers, 5 or 6 median suckers enlarged. Five longitudinal rows of suckers.

Hectocotylized arm: with 10- 12 quadriserial rows of normal suckers at base followed by 10 rows with ventral suckers (2 rows) normal but those in dorsal 2 rows are minute and separated from ventral rows by a fleshy transversely groove ridge. Sepia pharaonis.

*Tentacular club is small with well-developed keel, of a length about $15 \%$ of the tentacle.Hectocotylized arm shows a unique structure of hard enlarged wrapped around free edge endowed with seven transverse wrinkles without suckers (. Proximal and distal parts of hectocotylized carry erratically normal suckers Sepia elongata.

* Hectocotylus present on left ventral arm: 4 rows of normal size suckers proximally, 12 to 14 rows of reduced suckers medially, then normal size hectocotylus in 2 ventral series are displaced laterally, with gap between on proximal part of modified region Sepia prashadi.

* Club straight, slender; sucker-bearing surface convex, with 8 suckers in transverse rows; suckers differ slightly in size; several suckers of inner 2 or 3 rows very slightly larger than rest Sepia savignyi.

1-Sepia officinalis Linnaeus, 1758.

\section{(Plates 2, 3; A - K)}

Synonymy: None.

Mediterranean and world distribution. The species is cosmopolitan recorded in Mediterranean Sea (Forbes \& Hanley, 1852), Tunisian waters (Azouz, 1969; Ktari \& Salem, 1979), Adriatic sea (Riedle, 1970; Mondic \& Stzepcevic, 1985), Western Mediterranean (Boletzky, 1979), Jukic, 1981; Spanish Catalanian Sea (Sanchez, 1985), Turkish waters (Katagan \& Kocatas, 1990), Senegal waters (Bakhayokho, 1983), Eastern to South Africa Atlantic from Baltic and North Seas(Jereb\& Roper,2005). 
Local name: Sobbeit (Riad, 1993).

Local distribution. Alexandria watersSteuer (1939)\& Emam (1983). Alexandria Mediterranean waters from the Eastern Harbour, Abu Qir Bay (36m. depth to Roseta45m. depth, and to Sidi Krer West 10 m., and common on fish markets. (Riad, 1993).

Description: The body is broad and depressed, rounded posteriorly and truncated, it bears a notched termination to the body (Plate 2), and the head is much narrower than the body. Fourth pair of arms is crested provided with a clear white line extending along the edge (plate2). The shell antero posteriorly is round with posterior spine (Plate 3, A).Left arm IV hectocotylized is reduced in size, with 5-8 horizontal rows of reduced suckers (Plate $3 \mathrm{C}$ ). The tentacular club is provided with transverse rows of suckers, 5 or 6 in each, the median longitudinal row remarkably enlarged (Plate 3, B). The morphology of S.officinalis obtained from Alexandria Mediterranean waters as given above is in agreement with the literature.

Habitat: A demersal neritic species on sandy mud ground, occurring predominantly from the coastline to about $200 \mathrm{~m}$. (Jereb\&Roper, 2005).

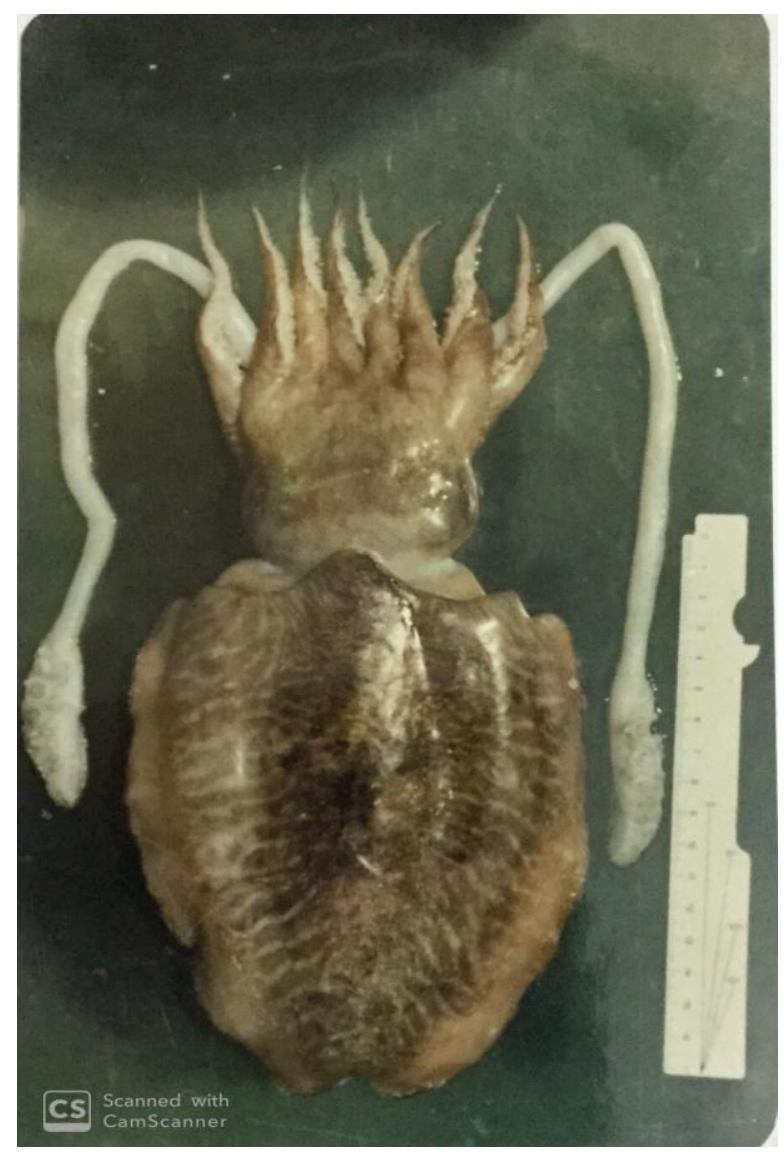

PLATE (2): Sepia officinalis 

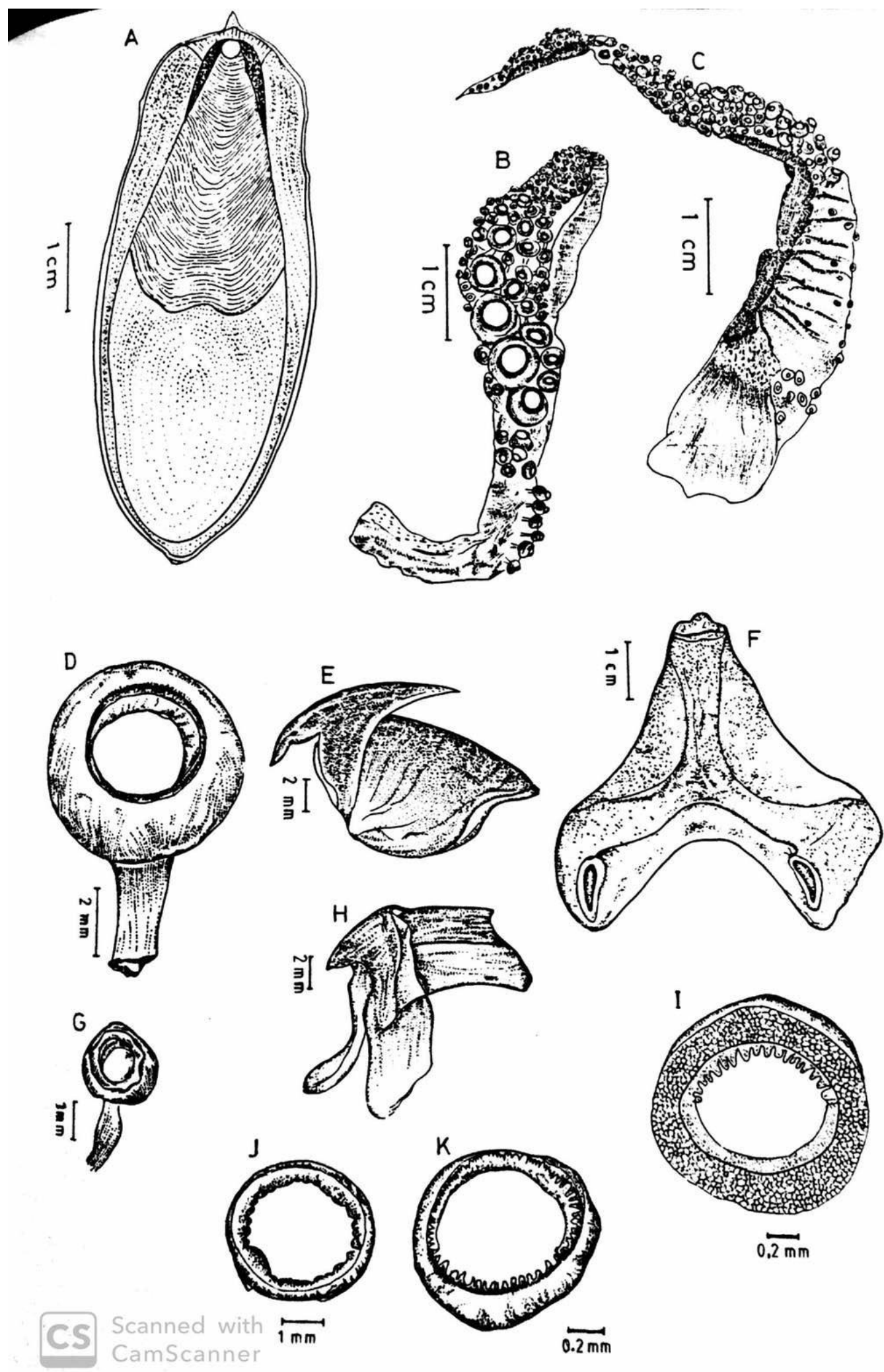

PLATE (3): Sepia officinalis 


\section{2-Sepia elegans Plainville, 1827.}

(Plates 4, 5, A - L)

Synonymy: Sepia biserialis B, Sepia rupellaria Ferrusac d'Orbigny, 1935 1948, Sepia italica Risso, 1854.

Mediterranean and world distribution. The species is cosmopolitan recorded in Mediterranean Sea (Forbes \& Hanley, 1852), Tunisian waters (Azouz, 1969; Ktari \& Salem, 1979), Adriatic Sea (Riedle, 1970; Mondic \& Stzepcevic, 1985), Western Mediterranean (Boletzky, 1979), Jukic, 1981; Spanish Catalonian Sea (Sanchez, 1985), Turkish waters (Katagan \& Kocatas, 1990), Senegal waters (Bakhayokho, 1983), Eastern to South Africa and Atlantic from Baltic and North Seas (Jereb \&Roper2005).

Local name - Sobbeit (.Riad, 1993).

Local distribution: Alexandria Mediterranean waters and Common on Alexandria fish markets.(Riad, 1993).

Description: The body and the mantle are oval in shape (Plate 4), the shell also ovate in shape (Plate 5A), slightly narrows below. Its dorsal margin with a prominent sharp angle (Plate 5A) . The swimming keel is clear and well developed. Each arm possesses 4 transverse rows of suckers. The tentacular club is short with 6 to 8 suckers on each transverse row, few of the suckers are enlarged while 3 are greatly developed in the center of the tentacular club being arranged longitudinally (Plate 5, B). Two thirds of the left arm IV hectocotilized possess about 9-11 zigzag rows of minute suckers (plate 5c), its distal third is only provided with4 rows of normal suckers (Plate5, C). The morphology of S.elegans from Alexandria waters is in agreement with the literature. Fifteen specimens were collected from Abu Qir fish market. The largest measured ML $5.6 \mathrm{~cm}$. and TW about $20 \mathrm{gm}$. : The smallest specimens showed ML $3.7 \mathrm{~cm}$. and TW $5 \mathrm{gm}$. (Jereb\& Roper, 2005).

Habitat: A small demersal species with a depth range of 30 to $430 \mathrm{~m}$. (Jereb\& Roper, 2005). 


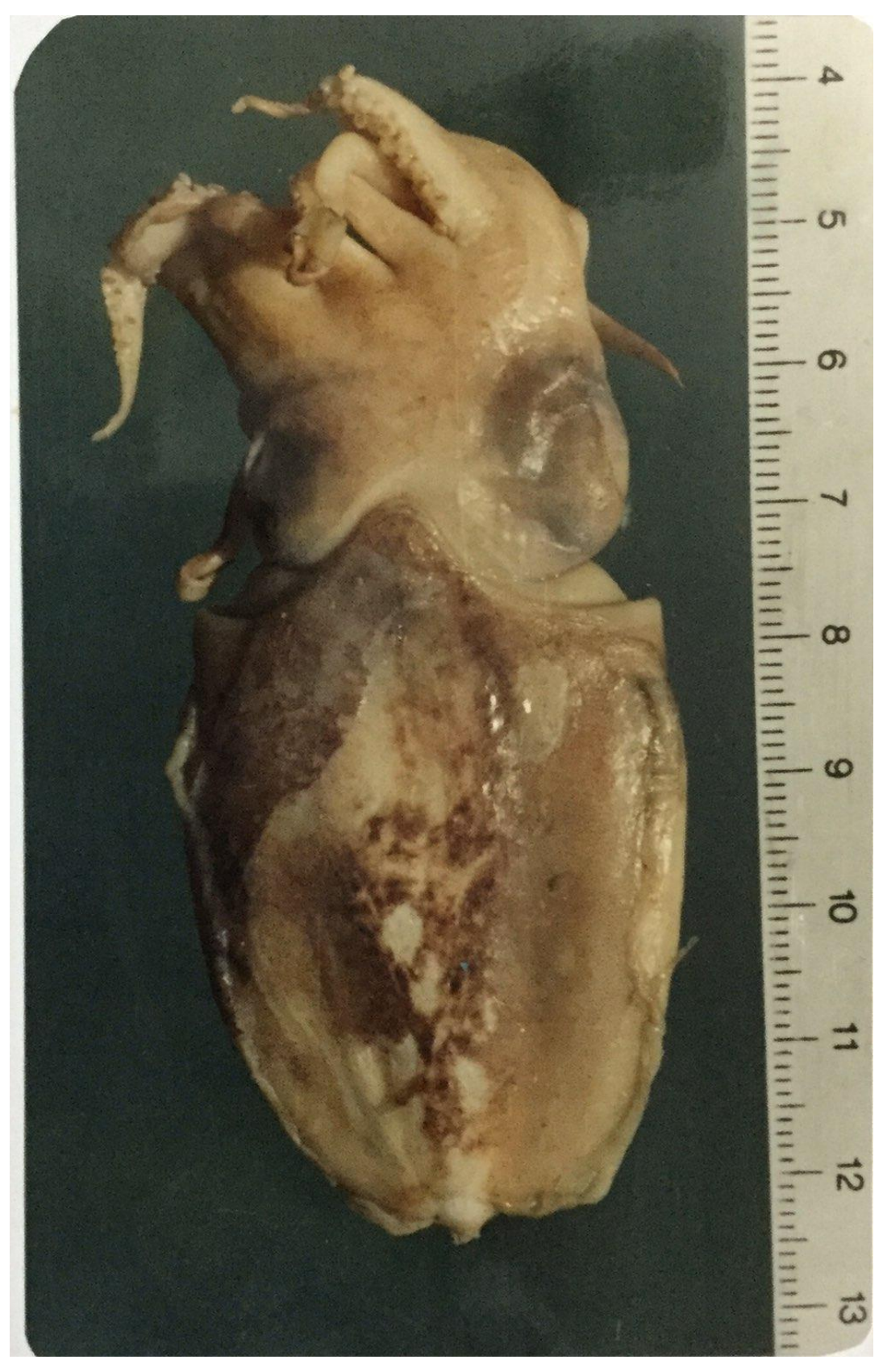

PLATE(4): Sepia elegans 

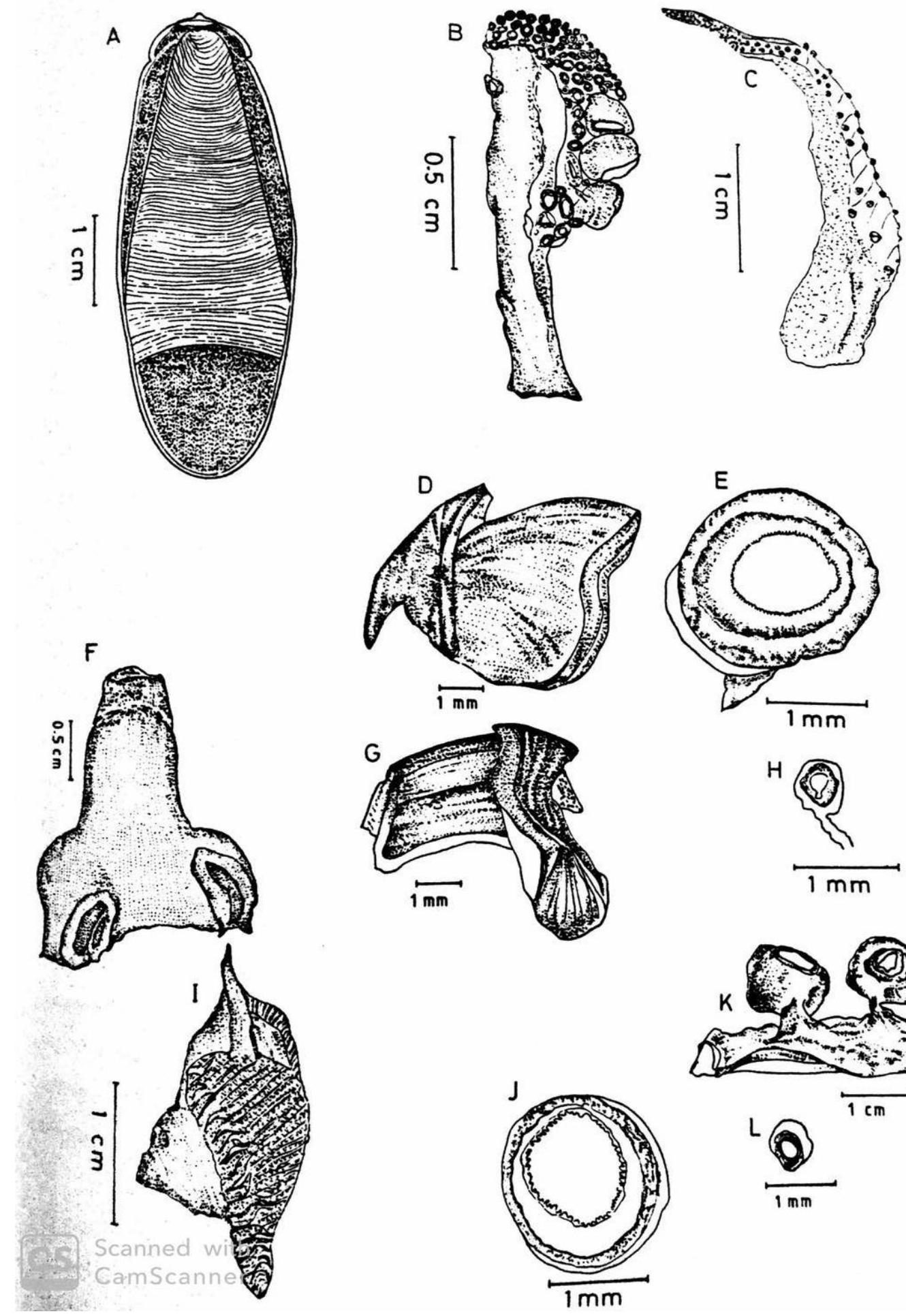

H
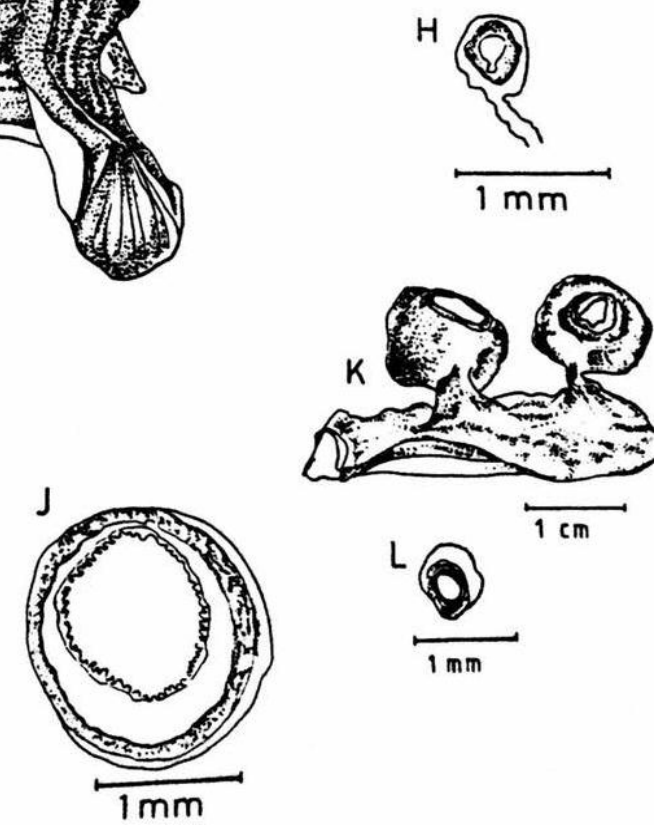

PLATE (5): Sepia elegans 
3- Sepia dollfusi Adam, 1941b.

(Plates 6, 7 \& 8)

Material:Two individuals were available. Both sexes were similar, a male of

$8.4 \mathrm{~cm}$. dorsal mantle length and a female of $13 \mathrm{~cm}$. dorsal mantle length.

Synonymy: None.

World distribution: Red Sea and Southern part of the Suez Canal. (Nesis, 1987).

Local name:Sobia.( Riad,2008a).

Local distribution: Suez Gulf (Emam and Saad, 1998, Gabr \& Hanlon, 1998), Suez Gulf and Red Sea (Riad, 200a). Aalexandria Mediterranean waters. (Riad, 2015).

Description:Mantle large with weak open mantle cavity (Plate 6). Arms are long, carry 4 rows of suckers (plate6). Arm sucker ring without teeth. Left arm IV hectocotylized modified in the about half terminal part forward by 12 transversal rows of 4 minute suckers (Plate7c). The shell is oval not rhomboidal, smoothly rounded posteriorly, its length almost equal to mantle length (Plate 8a-b-c).Tentacular club has 5-7 suckers in middle row larger than others (Plate $7 \mathrm{~b}$ ).Club suckers are gradually decreasing in size toward the edge of the tentacular club (Plate $7 \mathrm{~b}$ ). Club protective membranes are parallel in the carpal part and terminate on tentacular stalk without joining. More than 30 gill lamellae (Plate7d).

The previous description is in good accordance with the morphological description of Adam (1959\&1960) from Gulf of Suez and Gulf of Aqaba.

Habitat and biology: In the Egyptian waters Sepia dollfusi inhabiting the Red Sea and Suez Gulf waters and it is the primary fishery in the Suez Canal. Spawning was found to take place from January to April. The size at first maturity is 75 and $84 \mathrm{~mm}$ ML for males and females, respectively. Fecundity varied from 30 to 273 (Gabr et al., 1998). 


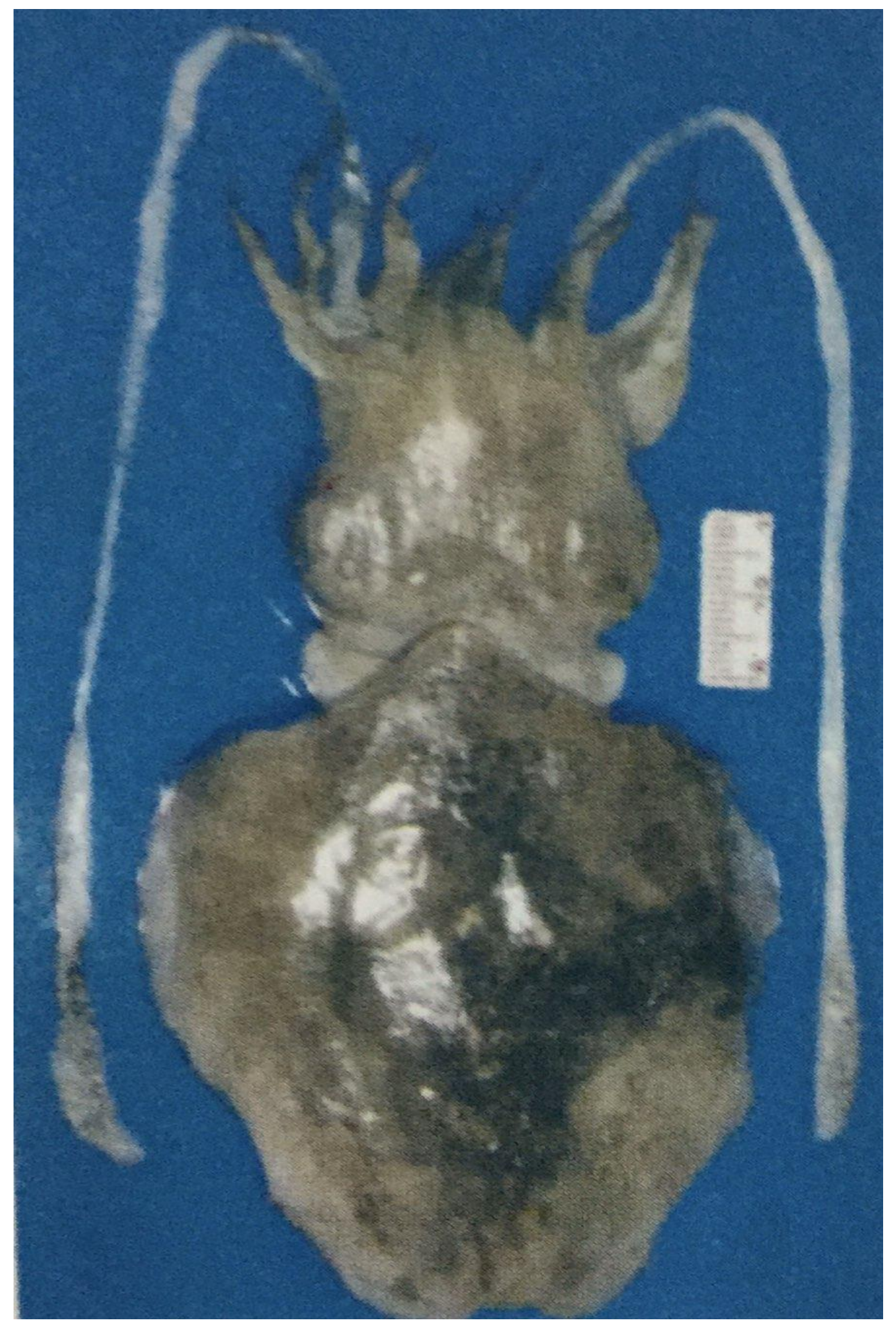

PLATE(6): Sepia dollfusi 


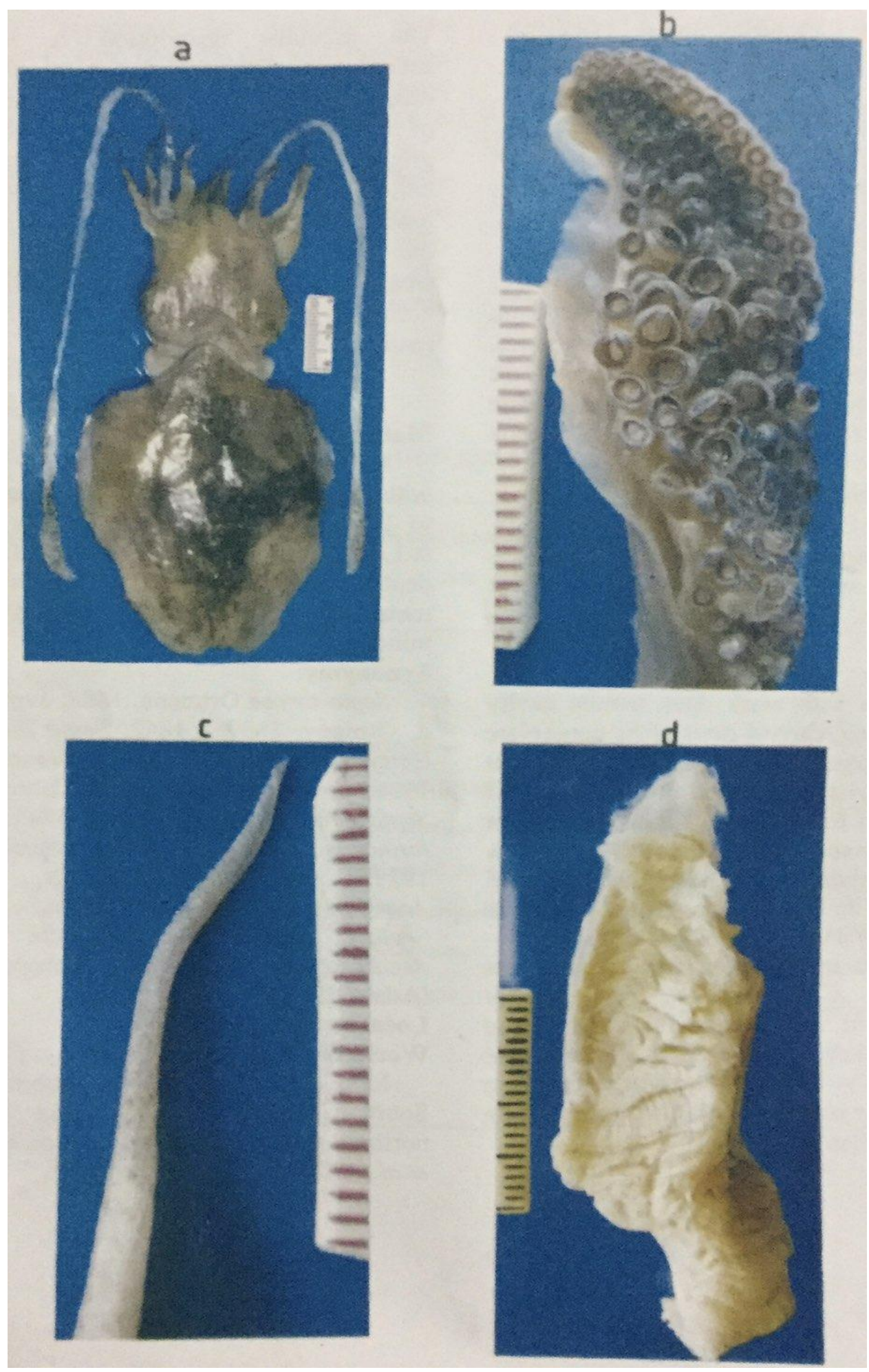

PLATE ( 7 ): Sepia dollfusi 


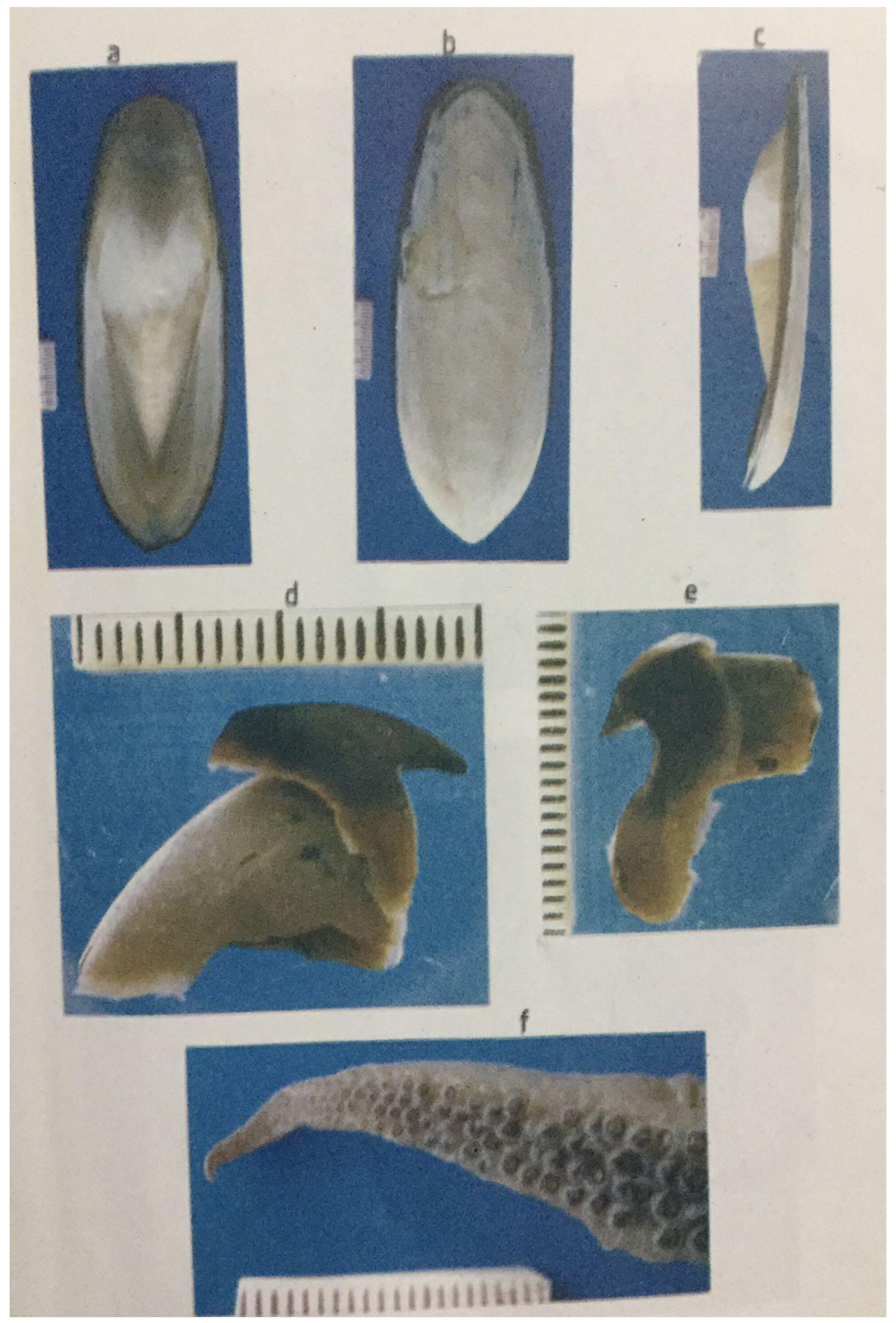

PLATE(8): Sepia dollfusi 


\section{4-Sepia pharaonis Ehrenberg, 1831 \\ (Plates 9, 10 \&11)}

Material: Five individuals with mantle length range from $9.5 \mathrm{~cm}$. to $14.7 \mathrm{~cm}$.

( 2 males and 3 females) were collected from Suez Gulf. The depth ranged between 64.5 meters and $86 \mathrm{~m}$.

Synonymy:Sepia torosa Ortmann, 1888; Sepia rouxii d, Orbigny, 1839 - 1842; Sepia formosana Berry, 1912; Crumenasepia hulliana Iredale, 1926; Crumenasepia ursulae Cotton, 1929; Sepia rouxi d, Orbigny, 1841; Sepia formosana Sasaki, 1929; Sepia tigris Sasaki, 1929. (Jereb and Roper, 2005) ; Acanthosepion rouxi Rochebrune,1884;Sepia singalensis Goodrich, 1896; Ascarosepion singhalensis Robson, 1927(Adam, 1960).

World distribution: Indo - Pacific: Red sea, Arabian Sea to South China Sea, East China Sea and northern and north Western Australia ( Jereb \&Roper,2005).

Local name: Sobia (Riad,2008a)

Local distribution: Suez Gulf (Gabr\& Hanlon, 1999). Suez Gulf and Red Sea (Riad, 2008a).

Description: Mantle broad. Fins wide, nearly as long as mantle ( Plate 9). The club is well differentiated and there are no suckers on the stem (Plate 10b). The middle part of the tentacular club bearing 8 transverse rows of suckers, 5 or 6 median suckers enlarged five longitudinal rows of suckers (Plate10b).. The swimming membrane of the tentacular club is well developed but does not extend on to the stem (Plate 10b). Protective membranes not meeting at base. Buccal membrane with a few minute suckers. Hectocotylized arm: with 10- 12 quadriserial rows of normal suckers at base followed by 10 rows with ventral suckers (2 rows) normal but those in dorsal 2 rows are minute and separated from ventral rows by a fleshy transversely grooved ridge (Plate 10c). Fins with longitudinal white band at base. Shell is flat, it's dorsal surface covered with small granules, the lateral chitinous margins being narrow (Plate11a-b). Inner cone limbs broaden; thicken posteriorly to form a distinct bulbous swelling, rounded interiorly. The striate zone nearly excavated at its posterior end and limited by the interior cone, while is a narrow rounded ridge. The posterior spine is short, pointed and well developed (Plate 10a-b). Gill with about 45 gill lamellae ( Plate 10d).

The previous description is in good accordance with Adam (1960) and Jereb \& Roper, (2005), except the presence of transverse Zebra stripe pattern especially in males, which may be faded in this study upon preservation in strong formalin solution and except for the additional character in present study, Gill with about 45 gill lamellae. In the present work the mantle length showed the largest specimen to be $14.7 \mathrm{~cm}$. and the smallest specimen to be $9.5 \mathrm{~cm}$., while according to Jereb \& Rober (2005) the common size range from 15 to $20 \mathrm{~cm}$. dorsal mantle length. Sepia pharaonis and Sepia ramani are very similar. Sepia ramani differs from Sepia pharaonis in having long club with 15 to 24 sub equal enlarged suckers. Sepia pharaonis has 6 enlarged medial club suckers, 3 or 4 of 
which are much larger than the rest. Sepia ramani has 14 to 16 transverse rows of normal size suckers on the proximal end of the hectocotylized arm, instead of 10 to 12 rows, as in Sepia pharaonis (Jereb \& Roper, 2005). According to Perera (1975) this species is easily differentiated from Sepia aculeate, by having the suckers of the two middle rows greatly enlarged.

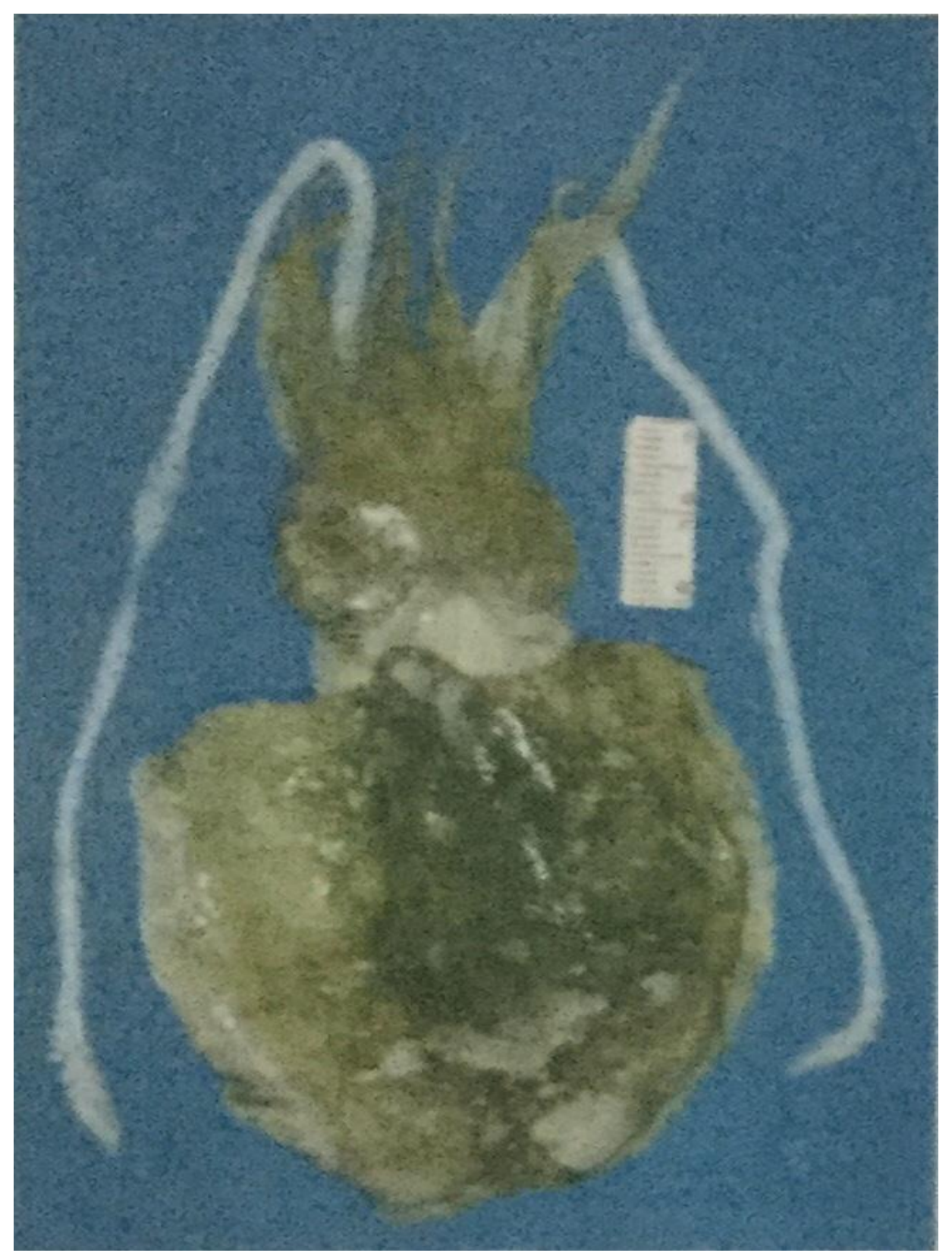

PLATE (9): Sepia pharaonis 


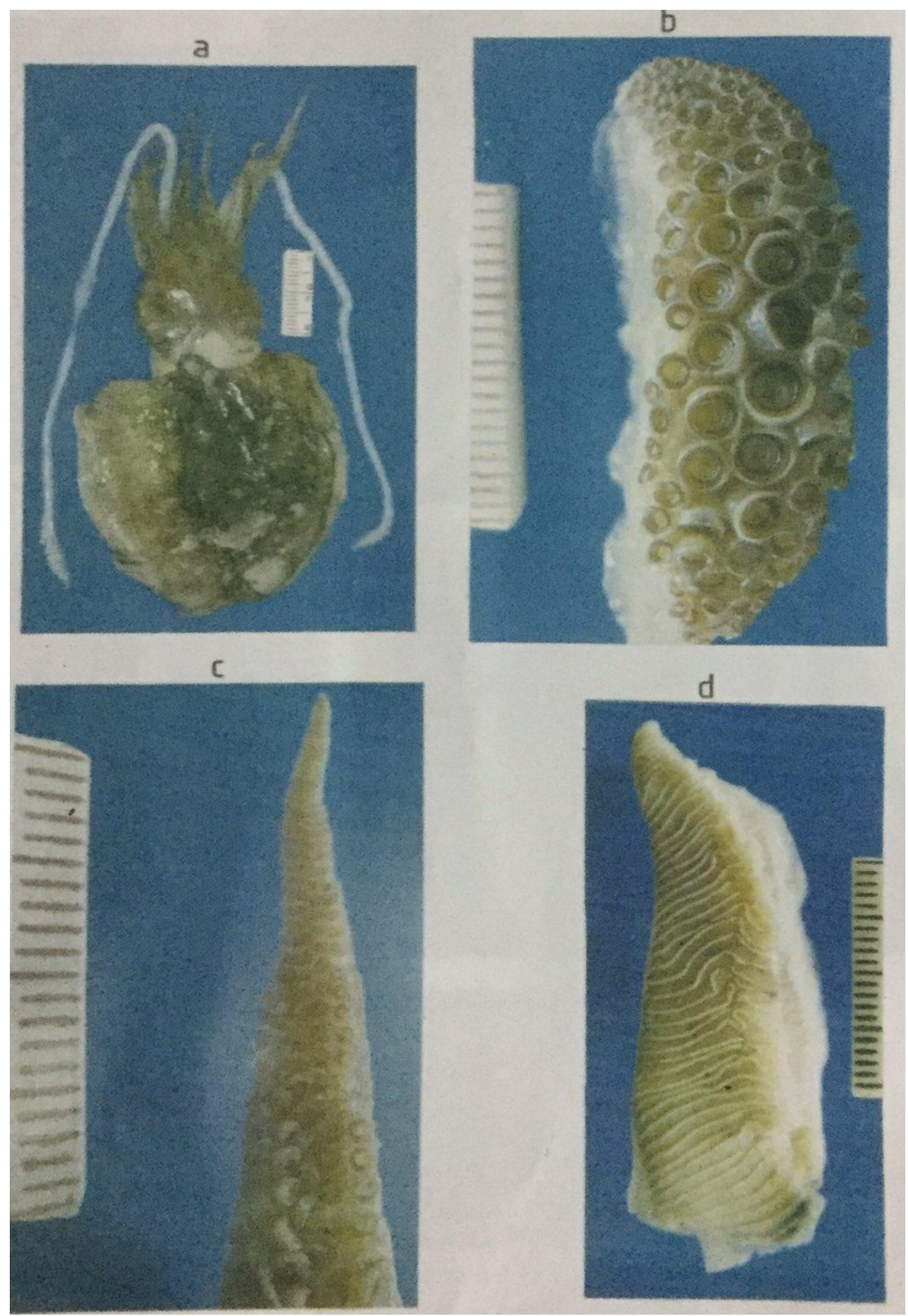

PLATE ( 10): Sepia pharaonis 


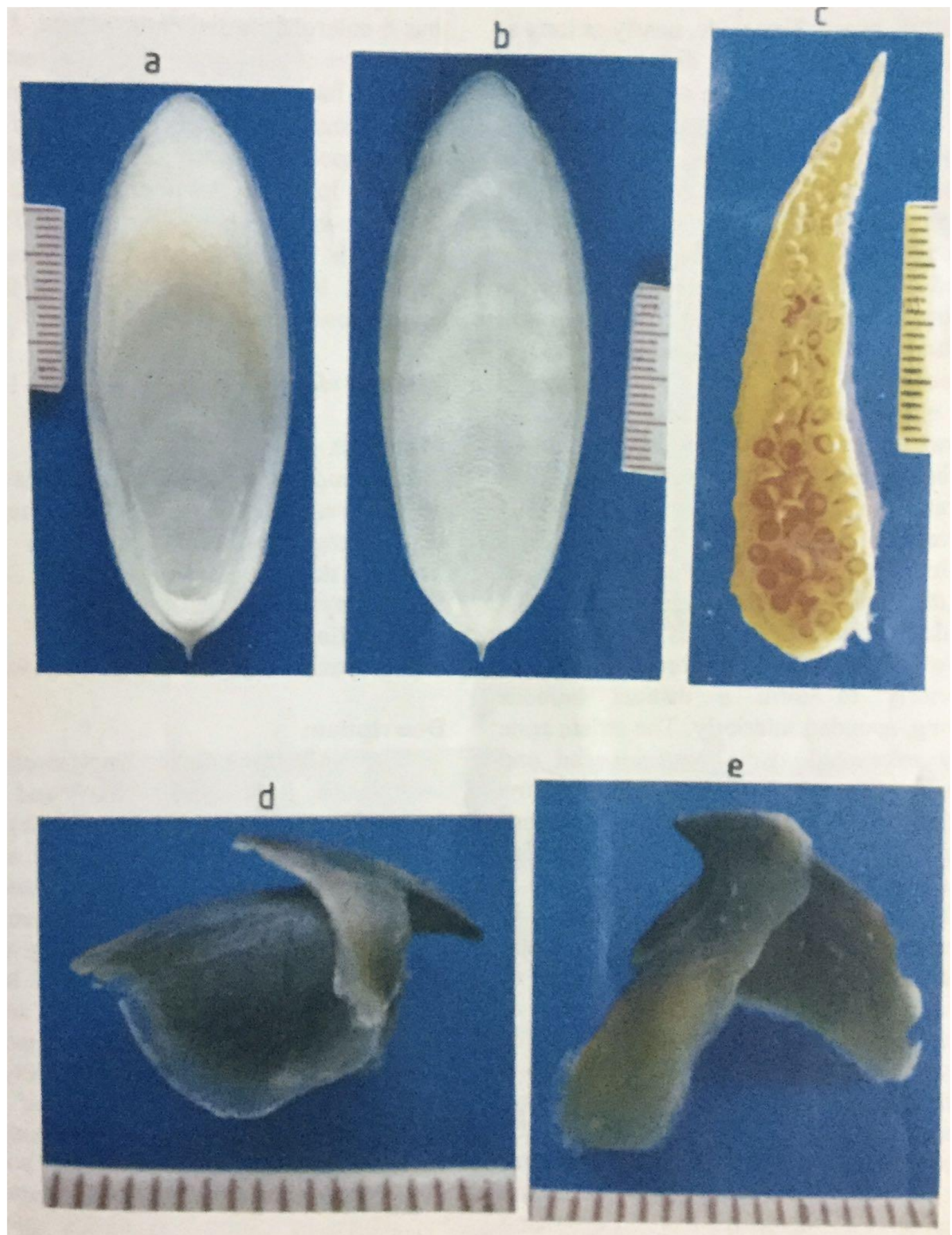

PLATE (11): Sepia pharaonis 


\section{5-Sepia elongata d' Orbigny, 1839 - 1842}

(Plates 12,13 \&14)

Material: One individual with mantle length $10 \mathrm{~cm}$.

Synonymy: None.

WorldDistribution: Indopacific and Red Sea ( Nesis, 1987).

Local name: Sobia (Riad, 2008a)

Local distribution: Suez Gulf, Red Sea ( Riad, 2008a).

Description: The body is elongate (Plate12). Shell swollen on ventral side, its thickness $7-10 \%$ and width $20-25 \%$ of shell length (Plate $14 \mathrm{a} \& \mathrm{~b}$ ), hard puffed out the ventral face and the outside cone with two broad later wings, and pointed spin is well developed (Plate 14 a \&b).

Arms are endowed with four series of suckers among which lightly bigger medians than lateral. Suckers in distal parts of arms, 1 st and 2nd pairs in males and of 2 nd and 3 rd pairs in females, disposed in 2 rows. Hectocotylized arm shows a unique structure of hard enlarged wrapped around free edge endowed with seven transverse wrinkles without suckers(. Proximal and distal parts of hectocotylized carry erratically normal suckers (Plate $14 \mathrm{~d}$ ). Tentacular club is small with well-developed keel, of a length about $15 \%$ of the tentacle, carries a series of five big suckers and the other tentacular suckers are tiny in comparison with this series of five, and erratically disposed (Plate 13b). The gill has 20 gill lamellae (Plate 14c).

The previous description is in good accordance with Adam, 1959, apart from, the gill with 45 gill lamellae in our specimens collected from Egyptian Red Sea, and in the present work the mantle length showed $10 \mathrm{~cm}$., while according to Jereb \& Rober( 2005), the mantle length up to $9.7 \mathrm{~cm}$.According to Adam, 1959 the species is especially characterized byhis lengthened form, Its tentacular club endowed with five suckers much bigger than the others, the remarkable hectocotylized arm and the shell has hard puffed out ventral face and the outside cone with two broad later wings.

The club and hectocotylus resemble that of Sepia trygonina, but the cuttlebone of Sepia elongata is thicker and the inner cone and the striae differ (Jereb \& Roper, 2005). 


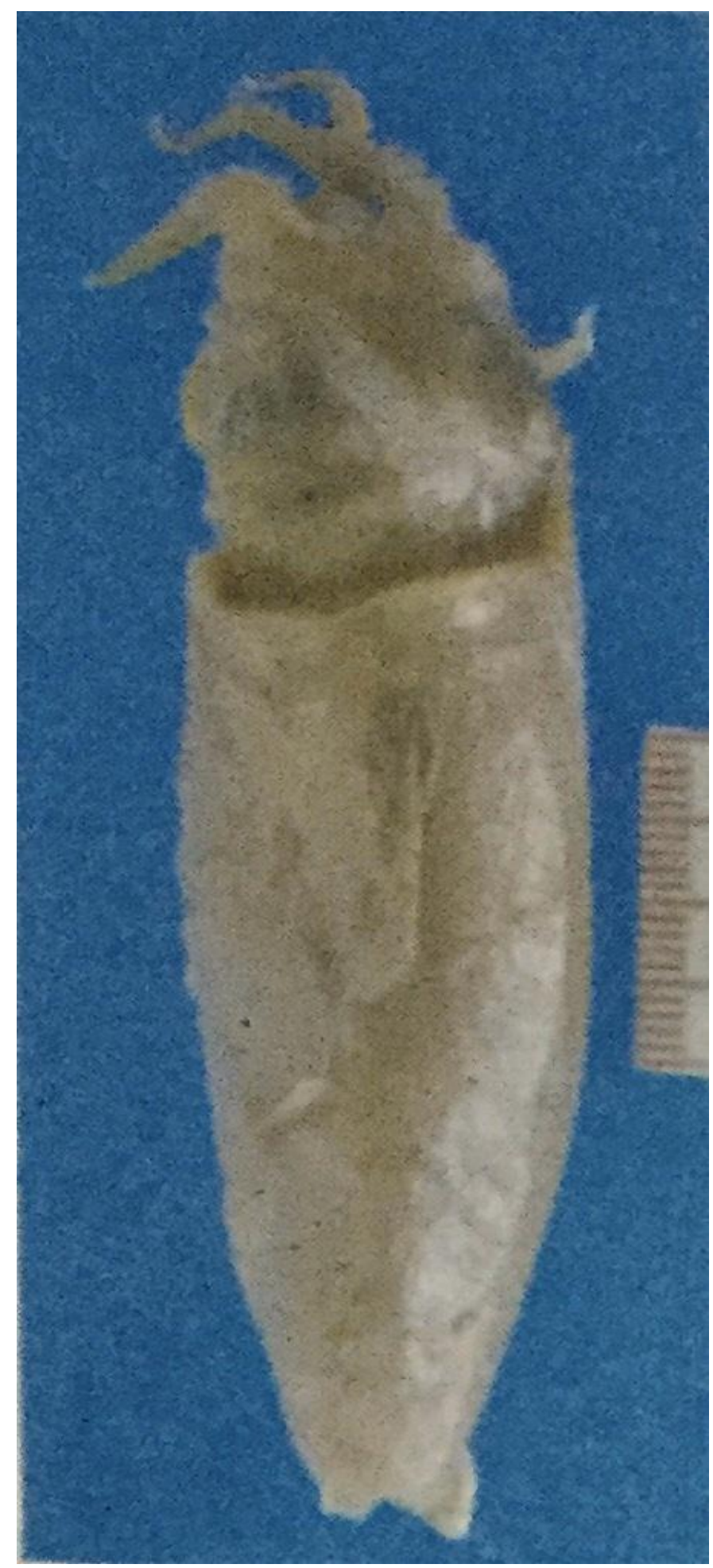

PLATE (12): Sepia elongate 


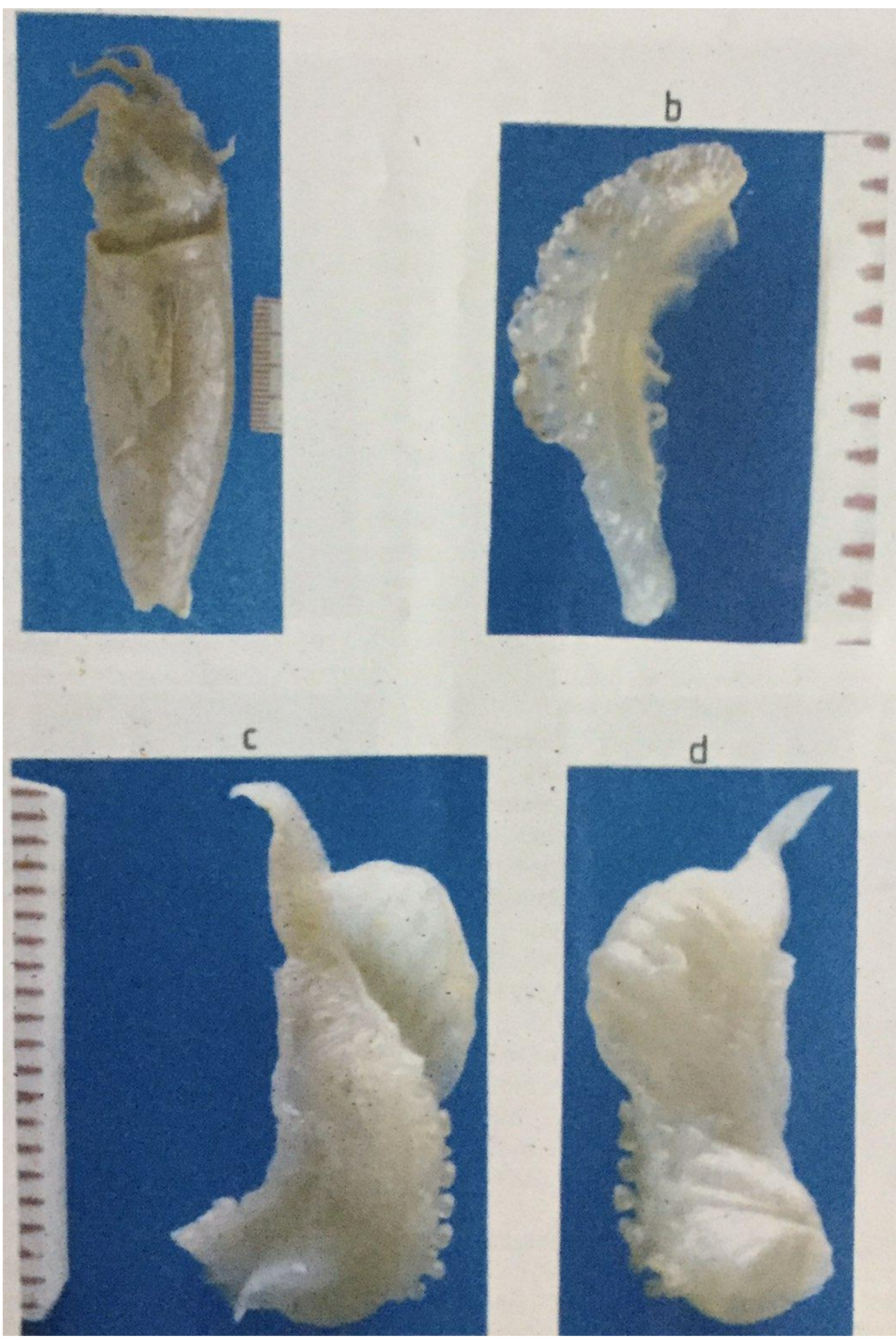

PLATE (13): Sepia elongate 


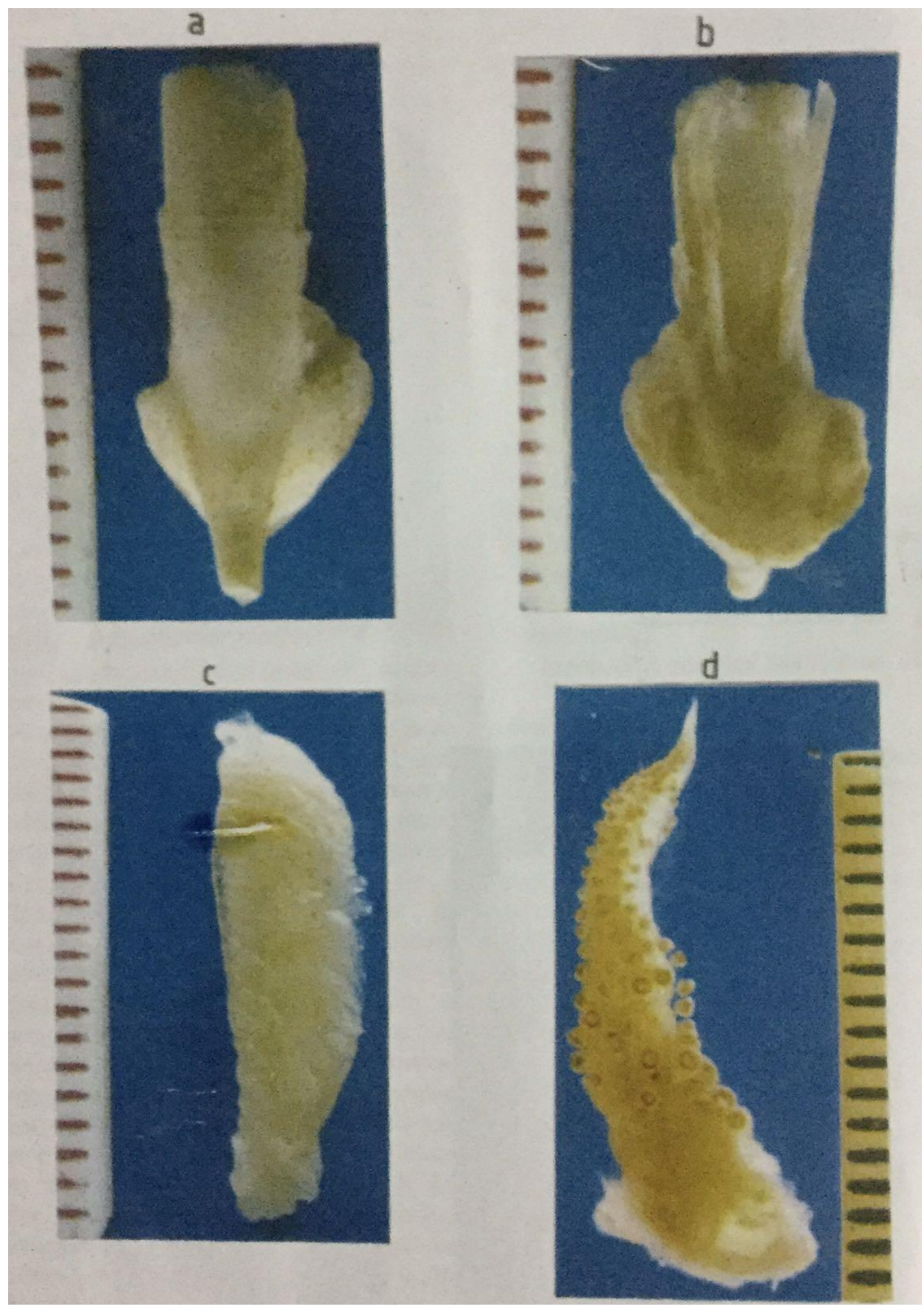

PLATE (14): Sepia elongate 


\section{6-Sepia prashadi Winckworth, 1936}

(Plates 15\& 16)

Synonyms: None.

Local name: Sobia. (Riad, 2008a)

Local distribution: Suez Gulf. ( Emam, 1983 \&1994).

Description: Male and female arms sub equal in length; protective membranes narrow. Arm suckers tetraseria. Male median arm suckers with greater diameter than marginal ones over most of arm length. Hectocotylus present on left ventral arm: 4 rows of normal size sucker proximally, 12 to 14 rows of reduced suckers medially, and then normal size hectocotylus in 2 ventral series is displaced laterally, with gap between on proximal part of modified region. Arm tip; oral surface of modified region wide, swollen, fleshy, with transversely grooved ridges. Suckers of hectocotylus in 2 ventral series are displaced laterally, with gap between on proximal part of modified region, becoming closer together distally. Club short (Plate16), oval; sucker-bearing surface flattened, with 3 to 5 suckers in transverse rows; suckers differ markedly in size: median 4 suckers extremely large, surrounded by moderately large suckers. Swimming keel of club extends proximally slightly beyond carpus; dorsal and ventral protective membranes not joined at base of club.

Cuttlebone outline oblong (Plate 16); bone triangular, obtuse anteriorly; bluntly rounded posteriorly; granulose; dorsal median rib distinct, broadens slightly anteriorly; ribs bordered laterally by distinct grooves; lateral ribs distinct. Chitin borders lateral and anterior margins of cuttiebone. Spine long, pointed, straight, directed dorsally, with dorsal and ventral keel. Striated zone convex; striated zone separated from outer cone by narrow, smooth marginal zones; sulcus shallow, narrow, flanked by rounded ribs, exiends entire length of cuttlebone.

Anterior striae shallow m- shape. Inner cone limbs are narrow anteriorly, broaden posteriorly; raised into rounded, thickened ledge; outer cone chitinous laterally, calcareous in expanded posterior part. Dorsal mantle has transverse zebra stripe patten in breeding males.( Jereb \& Roper 2005). 


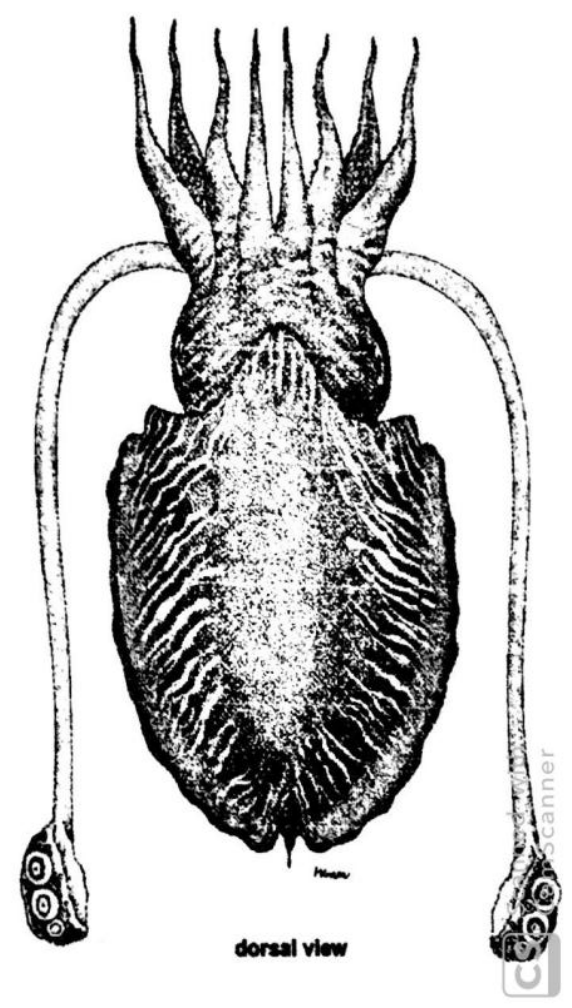

PLATE (15): Sepia parashadi (Redrawn from Jereb \& Roper, 2005)

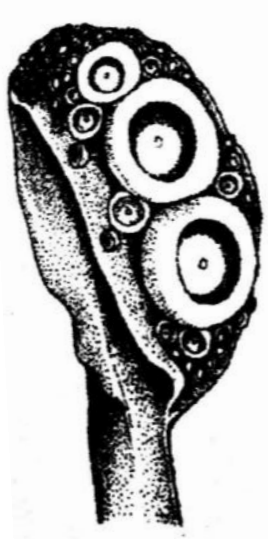

tentacular clab

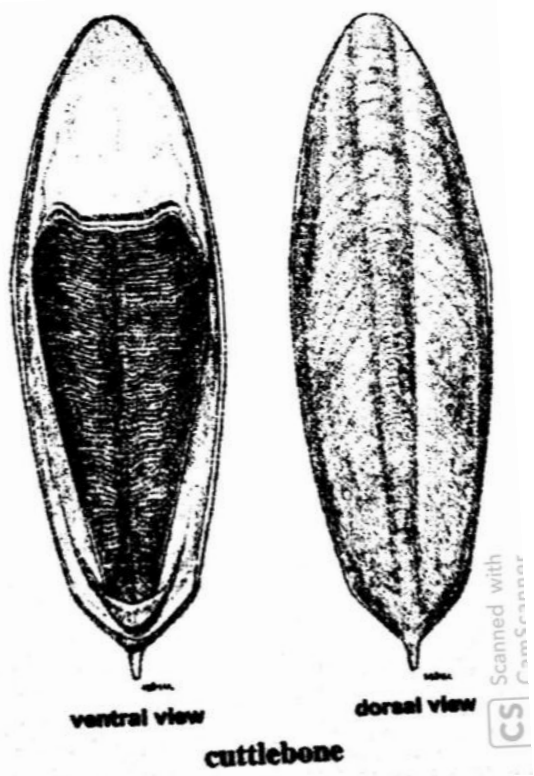

PLATE(16): Sepia parashadi (Redrawn from Jereb \& Roper, 2005) 


\section{7-Sepia savignyi Blainville, 1827}

(Plates 17\&18)

Sepia savignyi Blainville, 1827, Dictionnaire des Sciences Naturelles, 48: 285 [type locality: Red Sea). Frequent.

Synonyms: None.

World Distribution: Western Indian Ocean: Red Sea, Gulf of Aden, Arabian Sea, Persian Gulf and Saya-de-Malha Bank. Not recorded south of Socotra Island. (Jereb \& Roper,2005)).

. Local name: (Sobia (Riad, 2008a).

Local distribution: Red Sea (Emam, 1983\&Ibrahimet al,1993).

Description: Mantle broad, oval; ventral mantle margin emarginated. Fins wide. Male and female arms sub equal in length. Arm suckers tetraseria (Plate17). Club straight, slender; sucker-bearing surface convex, with 8 suckers in transverse rows; suckers differ slightly in size; several suckers of inner 2 or 3 rows very slightly larger than rest. Swimming keel of club terminates at proximal end of carpus (approximately).

Dorsal and ventral protective membranes not joined at base of club, extend proximal to carpus along stalk (Plate18). Buccal membrane with a few minute suckers. Cuttlebone outline oval; bone slightly acuminate, acute, anteriorly; bluntly rounded posteriorly; calcified with reticulate sculpture (Plate18); dorsal median rib and lateral ribs indistinct; median rib broadens anteriorly.

Chitin borders lateral and anterior margins of cuttlebone. Spine short, pointed. Striated zone flat, or slightly concave posteriorly; Slightly convex anteriorly on each side of sulcus; striated zone separated from outer cone by broad, smooth marginal zones; last loculus flat; sulcus shallow, wide, extends along striated zone only. Anterior striae are Inverted U-shape; limbs of inner cone extend anteriorly to approximately two-thirds length of striated zone. Inner cone limbs are narrow anteriorly, broaden posteriorly; outer margin of inner cone slightly raised as a slightly rounded ridge; not thickened; dull, not shiny; outer cone calcified narrow anteriorly, broadens posteriorly.

Colour: Light brown. Size: Up to 190 mm mantle length. .(Jereb \& Roper, 2005). 


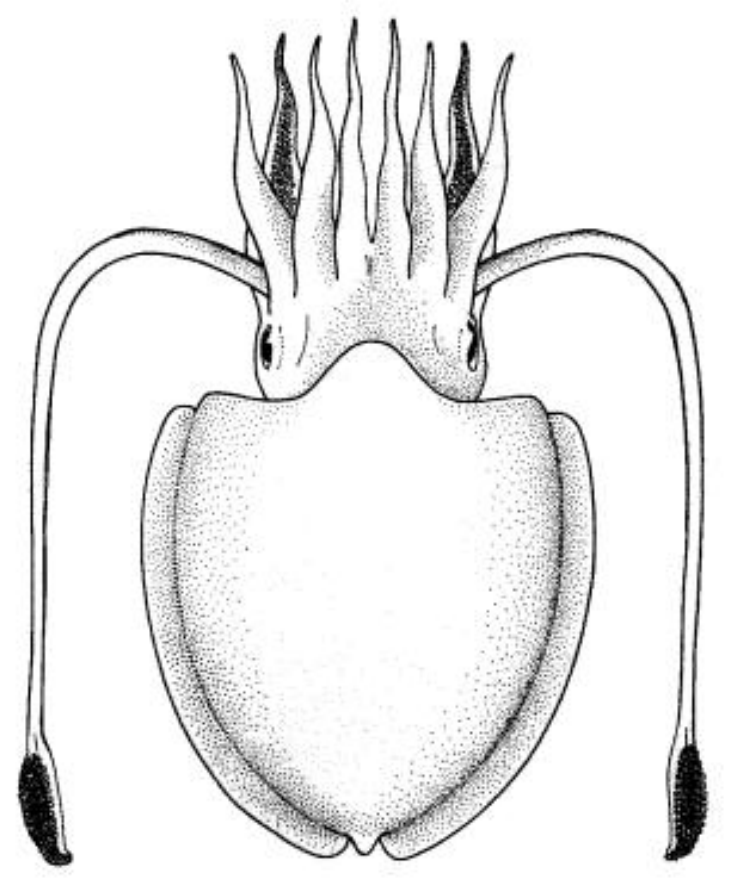

PLATE (17): Sepia savignyi (Redrawn from Jereb \& Roper, 2005)

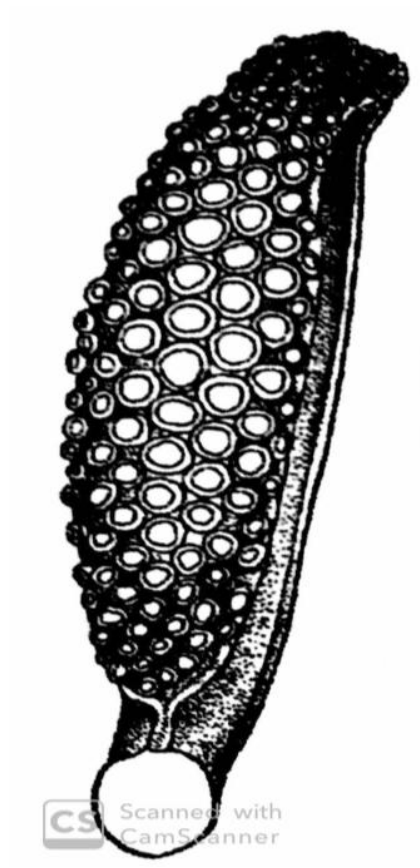

Tentacular club

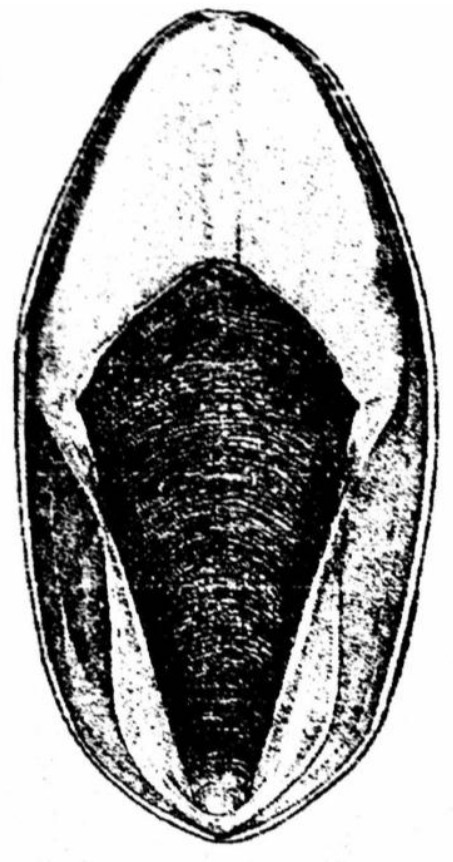

Shell

PLATE(18): Sepia savignyi (Redrawn from Jereb \& Roper, 2005) 
Family (b): Sepiolidae Leach, 1817.

Subfamily: Rossiinae Appellof, 1898.

Ginus: Rossia

Male with both dorsal arms hectocotylized by an expanded ventral membrane or thickened fold arm suckers of males not greatly enlarged tentacular clubs expanded with 5 to 16 transverse rows of medium suckers.( Jereb \& Roper, 2005)

Rossia macrosoma (Delle Chiaja, 1829)

[Plates 19, 20, 21, 22 and 23]

Material: Eleven individuals ranging between $2 \mathrm{~cm}$. mantle length weighing $3 \mathrm{~g}$. and 5.6 $\mathrm{cm}$. for mantle length of animal weighing $35 \mathrm{~g}$.

Synonymy: Sepiola macrosoma Delle Chiaja, 1829.

World distribution: Eastern Atlantic, North Sea. Mediterranean Sea. West Africa, Morocco, ( Jereb \&Roper 2005).

Local name: Sobbeit (Riad,1993)

Local distribution: Being recorded only from the area of Abu- Qir to Rosetta, Mediterranean ( Riad, 2000b), no more additional distribution of the species can be confirmed.

Description: Body broad and short, dorsal mantle border not fused to head. Fins oval shaped, wing-like. Colour reddish (Plate 19). Tentacular clubs with more than 8 sub equal suckers (Plates 20D\& 22C), all much smaller than arm suckers. Arms with 4 rows of well-developed suckers (Plates 20c \& 22b). Functional ink sac with regular anal flaps(plate $20 \mathrm{~g} \& 22 \mathrm{~g}$ ). Arms III and IV united by a broad web. Shell placed dorsally, rodshaped, with 2 narrow plates running along each side of the hind (Plates 20F\& 22F) region. Orbital pores open. Both arms I (dorsal) hectocotylized characterized by decrease in size of large basal suckers (in 2 rows) to smaller suckers (arranged in 4 rows in a rounded zigzag pattern)(Plates 20B \& 22A) and by the presence of a deep ridge and groove between horizontal sucker rows. 


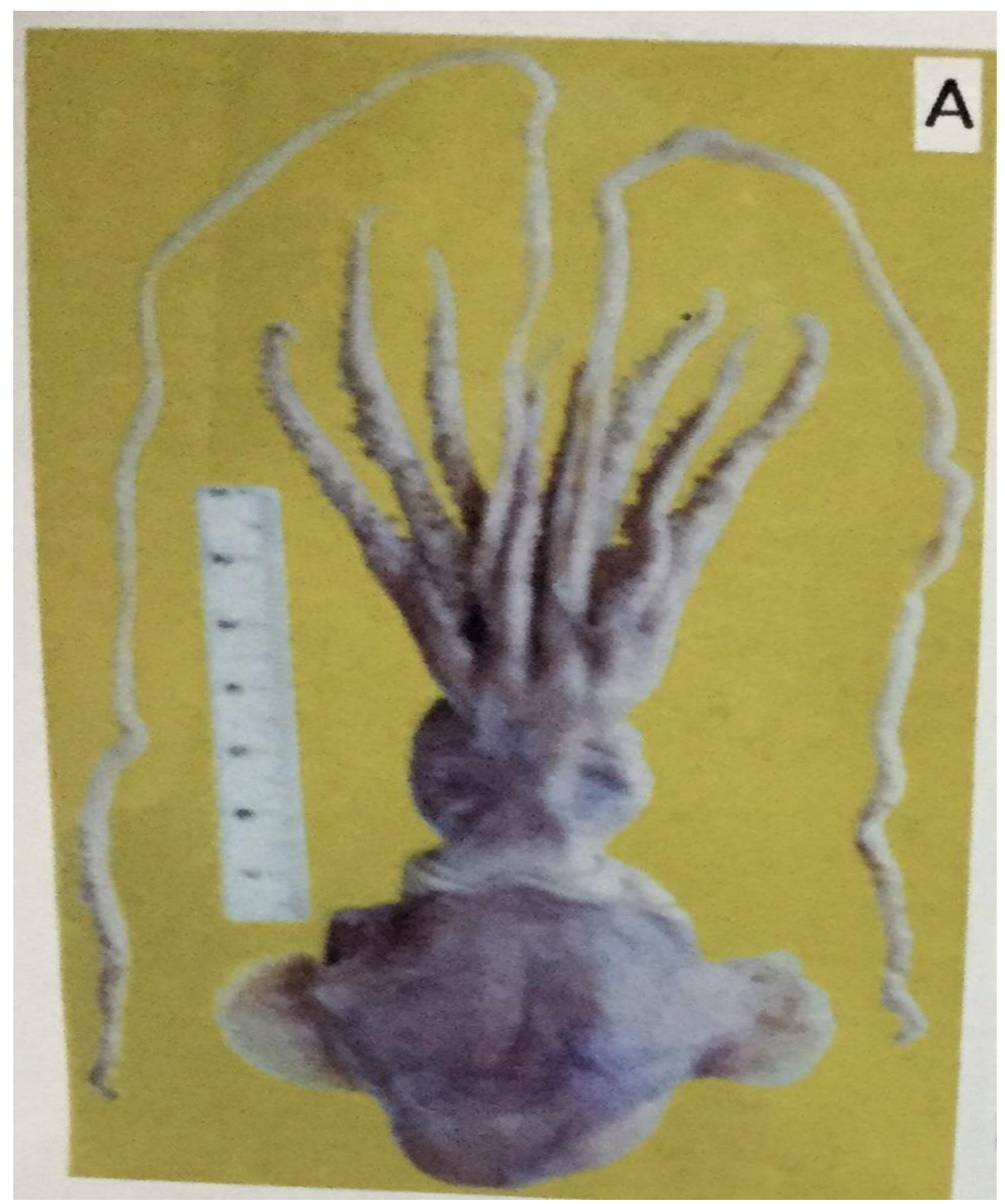

PLATE (19): Rossia macrosoma 


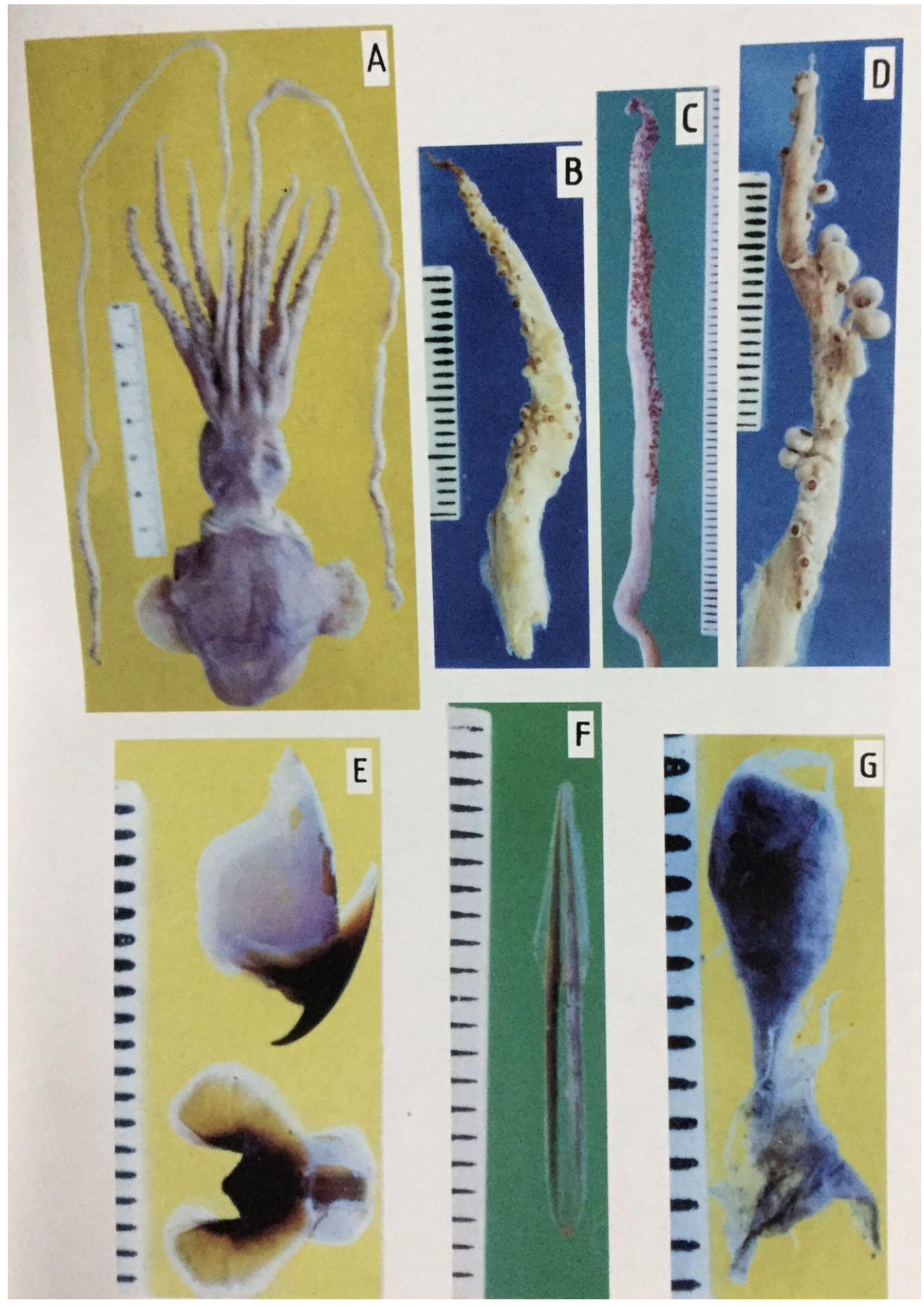

PLATE (20): Rossia macrosoma 


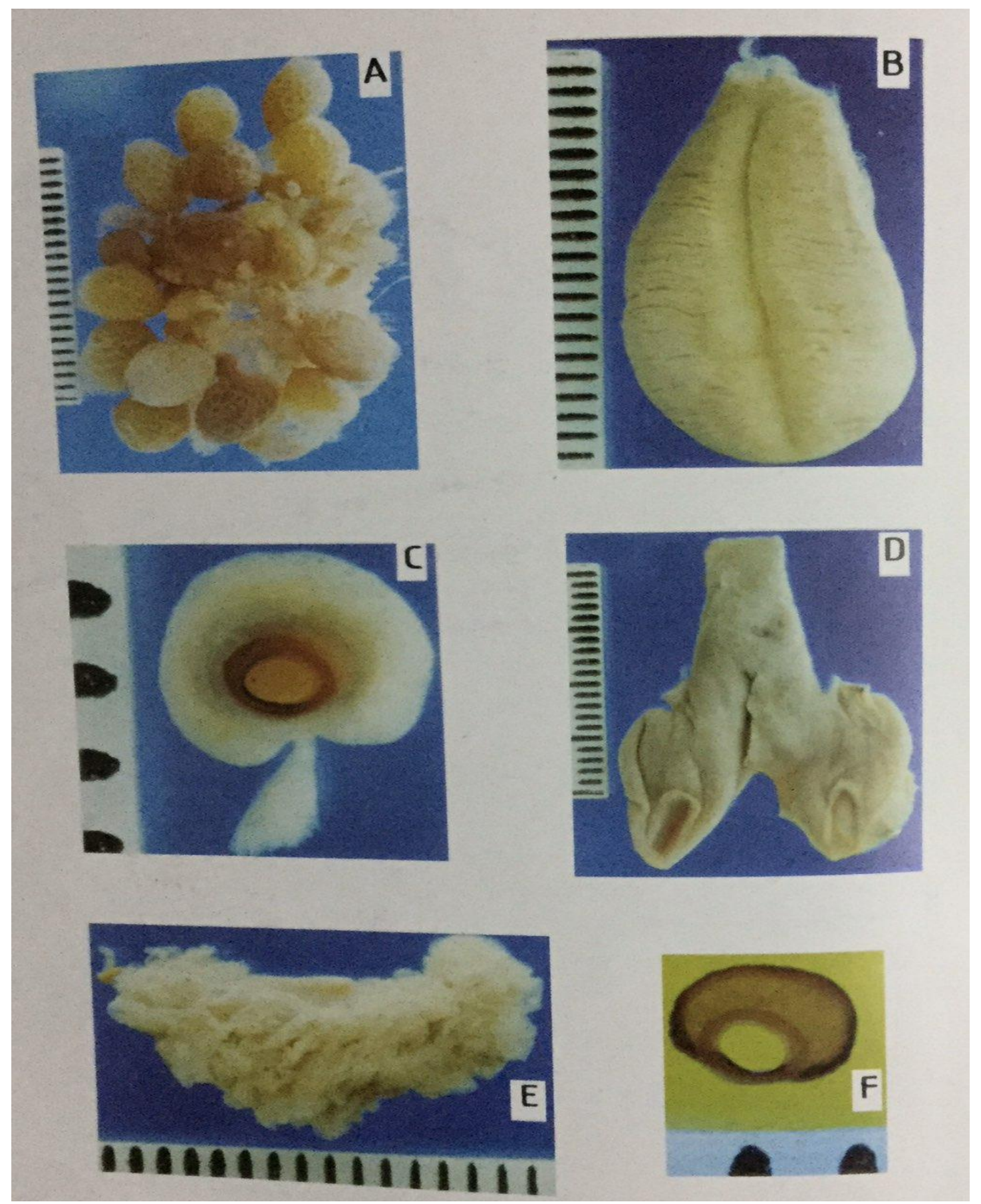

PLATE (21): Rossia macrosoma 
A

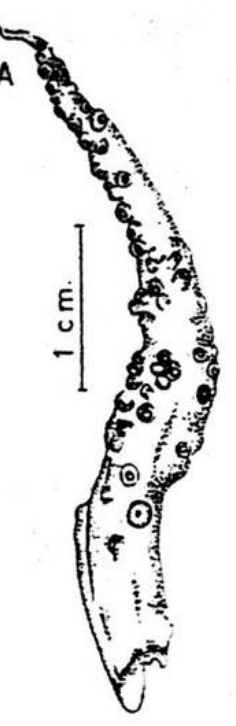

B

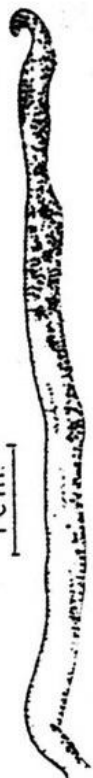

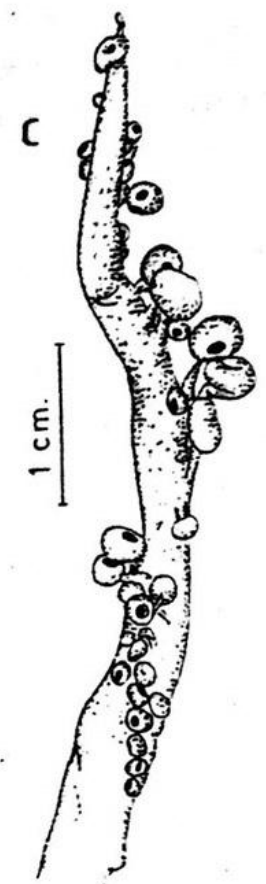
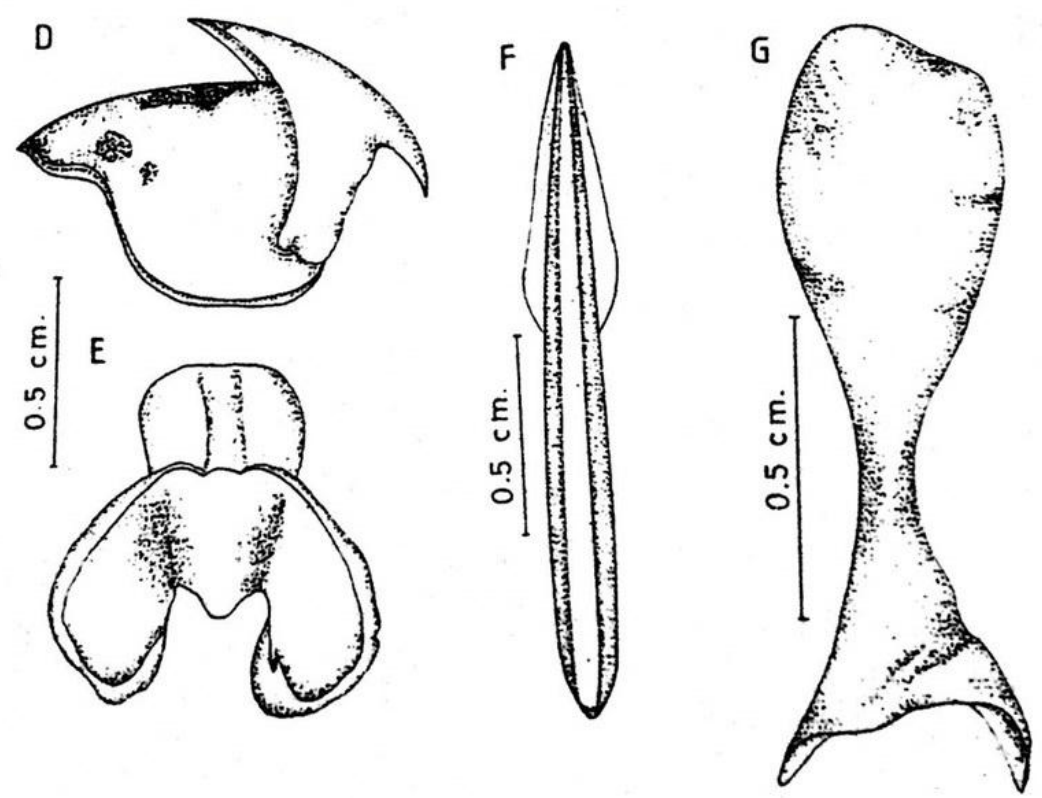

PLATE (22): Rossia macrosoma 

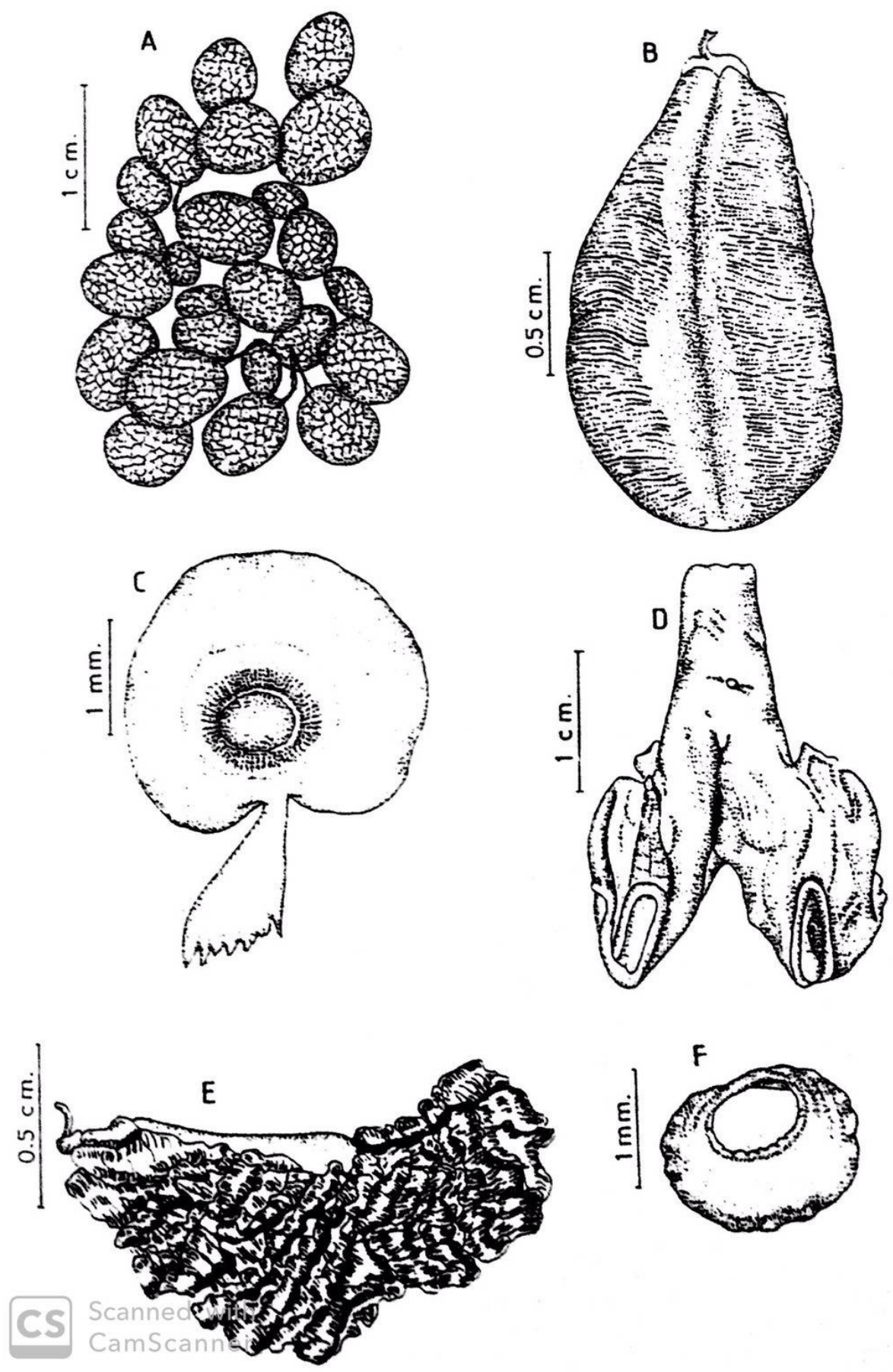

PLATE (23): Rossia macrosoma 


\section{ACKNOWLEDGMENT}

I am grateful to Dr. Safaa Fahmy, Dr. Marina Rafik and Miss Shery Rafik for their valuable assistance in finishing this monograph. I appreciate Dr. Magdy Khalil, Professor of Aquatic Ecology, Faculty of Science, Ain Shams University for all the help and support he has given me and for his efforts and stimulating discussion with facilitated finishing this monograph. I am indebted to Dr. Raouf Kilada, Professor of Biological Oceanography, University of New Brunswick, Saint John, for his assistance, he kindly offered.

\section{REFERENCES}

Adam, W. (1959). Les cephalopods de la mer Rouge Resultats scientifiques. Mission Robert Ph. Dollfus en Egypte. CNRS, Paris. pp. 125-192.

Adam, W. (1960). Cephalopoda from theGulf of Aqaba. Bull.Sea.Fish.Res.Stn.Haifa. 26: $1-27$.

Azouz, A. (1969).Etude des fons chalutables du Golfe de Tunis.

Bakhayokho, M. (1983). Biology of the cuttlefish Sepia officinalis hierredda off the Sengalese coast. In: Caddy, J.F. (Ed.), Advances in Assesment of World Cephalopod Resource. FAO Fish. Tech. Paper 231: 204-263.

Boletzky, S.V. ,(1979) . observation on the early post-embryonic development of Loligo vulgaris (Mollusca, Cephalopoda). Rapp. Comm. Int. Mer Medit., 25 /26. 10: 155-158.

Edwards, A.J. and Head, S.M. (1987). Red Sea. Pergamon Press, Oxford, 433 pp.

Emam, W. M. (1983). Morphometric studies on three species of the genus Sepia from the Red Sea. Bulletin of the Institutes of Oceanography and Fisheries, 9:341346.

Emam, W. M. and Saad, A. A. (1998). Morphometric studies and population dynamics of Sepia dollfusi (Cephalopoda: Sepiidae) from the Suez Gulf- Red Sea. Egypt. J. Aquat. Biol. Fish., 1 (1): 117-138.

Gabr, H.R.; Hanlon, R.T.; Hanafy, M.H. and El-Etreby, S.G. (1998). Maturation, fecundity and seasonality of reproduction of two commercially valuable cuttlefish, Sepia pharaonis and Sepia dollfusi, in the Suez Canal. Fish Res., 36: 99-115. 
Gabr, H. R.; Hanlon, R.T. ; El-Etreby, S.G. and Hanafy, M.H. (1999). Reproductive versus somatic tissue growth during the life cycle of the cuttlefish Sepia pharaonis Ehrenberg, 1831. Fish. Bull. 97: 802-811.

Hassan, A. K. (1974). Studies on bottom Molluscs (gastropods and bivalves) in Abou Kir Bay. M. Sc. Thesis, Facul., Sci, Alex. Univ., 319 pp.

Jereb, P. and Roper, C.F.E. ( 2005). FAO Species Catalogue for Fishery Purposes. Cephalopods of the world. 1 ( 4): 262 pp.

Jukic, S. (1981).State of the cephalopoda ressources along the Eastern Adriatic coast and possible conflicts between trawl and artisanal fisheries. Rapp. Comm. Int. Mer MEDIT., 29,8: 237-240.

Ktari, N. H. and Salem, M. H. AQ. (1979). Production des cephalopods en Tunisie. Rapp. Comm. Int. Mer. MDIT., 25-26,10:153-154.

Katagan, T. and Kocatas, A.( 1990). Note preliminaire sur les cephalopods des Eaux Torques. Rapp. Comm. Int. Mer. Medit., 32, 1: 242.

Mondic, S. and Stzepevic , J. ,(1985). Movements migratoires de quelques especes de cephalopods economiquement importantes dans L'Adriatique meridionale. Rapp. Comm. Int. Mer Medit. 27 , $5: 213-216$.

Nesis, K.N. (1987). Cephalopods of the world. Squid, cuttlefishes, octopuses, Neptune City, NJ: T.F.H. Publications Inc., Ltd, 351 pp.

Perera, N.M.P.J. (1975). Taxonomic study of the cephalopods, particularly the Teuthoidea (squids) and Sepioidea (cuttlefish) in the water around Sri Lanka. Bull.Fish.Res.Stn.,Colombo, 26(1-2): 45- 60.

Riad, R. (1993). Studies on cephalopod molluscs of the Mediterranean waters of Alexandria. M. Sc. Thesis, Ocean. Dept., Fac. Sci., Alex. Univ., 246 pp.

Riad, R. (2000a).Biological and taxonomical studies on octopuses (Octopoda: Cephalopoda) from the Egyptian Mediterranean waters. Ph.D., Department of Oceanography, Faculty of Science, Alexandria Univeristy.236 pp.

Riad, R. (2000b). First record of Rossia macrosoma and Octopus defilippi (Cephalopoda: Mollusca) in the Egyptian Mediterranean waters. Bull. Nat. Inst. Of Ocean. \& Fish., A.R.E., (26): 167-182.

Riad, R. (2008a). Morphological and taxonomical studies on some cephalopods from the Suez Gulf and Red Sea. Egypt J. Aquat. Res. 34:176-201. 
Riad,R. (2008b). New record genus and species of the squid Sepioteuthis lessoniana (Cephalopoda: Loliginidae) from the Egyptian Mediterranean waters. African J. Biol. Sci. 4 (1): 1- 11.

Riad, R. (2015). First record of the cuttelfish Sepia dollfusi (Cephalopoda: Sepioidea) from the Egyptian Mediterranean water. Egypt. J. Aquat. Biol. \& Fish., 19(3):17.

Riedle, R. (1970). Fauna und flora der Adria, pp.463 - 469.

Robson, G.C. (1926). Report on the Mollusca (cephalopoda). Cambri Suez Canal.

Steuer, A. (1939) the fishery grounds near Alexandria.XIX-Mollusca.Notes and Memories, No.33: 1-152.

Sanchez, P., 1985. La peche de cephalopods sur la cote catalane. Rapp. Comm. Int. Mer Medit., 29, 8: 233-236.

Savigny, J. C. (1817). Description de l' Egypte. II, pl. I.

Steuer, A. (1939) the fishery grounds near Alexandria.XIX-Mollusca .Notes and Memories, No.33: 1-152. 